\title{
Anti-proliferative and anti-secretory effects of everolimus on human pancreatic neuroendocrine tumors primary cultures: is there any benefit from combination with somatostatin analogs?
}

\author{
Amira Mohamed ${ }^{1,2}$, David Romano ${ }^{1}$, Alexandru Saveanu ${ }^{1,2}$, Catherine Roche ${ }^{2}$, \\ Manuela Albertelli ${ }^{3}$, Federica Barbieri ${ }^{3}$, Thierry Brue ${ }^{1,4}$, Patricia Niccoli ${ }^{5}$, Jean- \\ Robert Delpero6, Stephane Garcia ${ }^{8}$, Diego Ferone $^{3}$, Tullio Florio ${ }^{3}$, Vincent \\ Moutardier ${ }^{9}$, Flora Poizat ${ }^{7, *}$, Anne Barlier ${ }^{1,2, *}$ and Corinne Gerard ${ }^{1}$ \\ ${ }^{1}$ Aix Marseille Univ, CNRS, CRN2M, Marseille, France \\ ${ }^{2}$ APHM, Conception Hospital, Molecular Biology Laboratory, Marseille, France \\ ${ }^{3}$ Department of Internal Medicine and Center of Excellence for Biomedical Research, University of Genova, Genova, Italy \\ ${ }^{4}$ APHM, Conception Hospital, Endocrinology Department, Marseille, France \\ ${ }^{5}$ Paoli Calmettes Cancer Institute, Oncology Department, IPC CoE-ENETS, Marseille, France \\ ${ }^{6}$ Paoli Calmettes Cancer Institute, Surgery Department, IPC CoE-ENETS, Marseille, France \\ ${ }^{7}$ Paoli Calmettes Cancer Institute, Biopathology Department, IPC CoE-ENETS, Marseille, France \\ ${ }^{8}$ APHM, North Hospital, Pathology Laboratory, Marseille, France \\ ${ }^{9}$ APHM, North Hospital, Surgery Department, Marseille, France \\ "These authors have contributed equally to this work \\ Correspondence to: Corinne Gerard, email: corinne.gerard@univ-amu.fr \\ Keywords: everolimus, somatostatin analogs, human pancreatic neuroendocrine tumors, primary culture, co-treatment \\ Received: July 26, $2016 \quad$ Accepted: March 22, $2017 \quad$ Published: April 10, 2017 \\ Copyright: Mohamed et al. This is an open-access article distributed under the terms of the Creative Commons Attribution License \\ 3.0 (CC BY 3.0), which permits unrestricted use, distribution, and reproduction in any medium, provided the original author and \\ source are credited.
}

\section{ABSTRACT}

Therapeutic management of gastroenteropancreatic neuroendocrine tumors (GEP-NETs) is challenging. The mammalian target of rapamycin (mTOR) inhibitor everolimus recently obtained approval from the Food and Drug Administration for the treatment of patients with advanced pancreatic neuroendocrine tumors (pNETs). Despite its promising antitumor efficacy observed in cell lines, clinical benefit for patients is unsatisfactory. The limited therapeutic potential of everolimus in cancer cells has been attributed to Akt activation due to feedback loops relief following mTOR inhibition. Combined inhibition of Akt might then improve everolimus antitumoral effect. In this regard, the somatostatin analog (SSA) octreotide has been shown to repress the PI3K/ Akt pathway in some tumor cell lines. Moreover, SSAs are well tolerated and routinely used to reduce symptoms caused by peptide release in patients carrying functional GEP-NETs. We have recently established and characterized primary cultures of human pNETs and demonstrated the anti-proliferative effects of both octreotide and pasireotide. In this study, we aim at determining the antitumor efficacy of everolimus alone or in combination with the SSAs octreotide and pasireotide in primary cultures of pNETs. Everolimus reduced both Chromogranin A secretion and cell viability and upregulated Akt activity in single treatment. Its anti-proliferative and anti-secretory efficacy was not improved combined with the SSAs. Both SSAs did not overcome everolimus-induced Akt upregulation. Furthermore, caspase-dependent apoptosis induced by SSAs was lost in combined treatments. These molecular events provide the first evidence supporting the lack of marked benefit in patients co-treated with everolimus and SSA. 


\section{INTRODUCTION}

Gastroenteropancreatic (GEP) neuroendocrine tumors (NETs) is a rare and heterogeneous group of tumors, with recent increased incidence and prevalence [1]. Pancreatic neuroendocrine tumors (pNETs) constitute a distinct subset of GEP-NETs which behave and respond to systemic treatments differently to other GEP-NETs (see [2] for a review). The majority of pNETs are sporadic but some are associated with inherited genetic syndromes such as multiple endocrine neoplasia type 1 syndrome (MEN1) and tuberus sclerosis. They are classified as functional (10$30 \%$ ) or non functional (50-80\%), based on their specific pancreatic hormone hypersecretion [3]. Treatment options range from curative surgery for localized resectable disease to palliation with medical therapies including somatostatin analogs (SSAs), chemotherapy and targeted treatments for advanced and metastatic pNETs [4]. The SSAs octreotide and lanreotide are currently used to reduce symptoms caused by peptides release in a majority of patients carrying functional GEP-NETs [5]. These effects have been credited to their binding to the somatostatin receptor subtype 2 (SST2). SSAs anti-proliferative role has been investigated in PROMID and CLARINET studies. Both long acting octreotide and lanreotide significantly prolonged progression free survival (PFS) respectively in patients with well-differentiated metastatic midguts GEPNETs and metastatic pNETs [6, 7].

The PI3K/Akt/mTOR pathway integrates growth factor signals and plays a central role in regulating multiple cellular processes such as cell growth, survival and protein synthesis. Several studies have suggested the involvement of this pathway in pNET tumorigenesis and progression. Whole exome sequencing of pNETs identified inactivating mutations of two major negative regulators of the PI3K/Akt/mTOR pathway, the phosphatase and tensin homolog (PTEN) and the tuberous sclerosis 2 (TSC2), in $14 \%$ of tumors [8]. Moreover, Missiaglia et al. have shown that PTEN and TSC2 downregulation was associated with shorter PFS and overall survival of pNETs patients [9]. On the contrary, activated levels of Akt and mTOR have been observed in a subset of pNETs but without significant correlation with clinicopathological features [10-12]. Overall, these clues have given the rational for the use of mTOR inhibitors in the treatment of pNETs. Everolimus, a mTORC1 inhibitor, induces antiproliferative effects in the pNET cell line BON [13]. In the phase III RADIANT 3 trial, everolimus significantly prolonged PFS in patients with progressive advanced pNETs compared with placebo [14]. Thus everolimus obtained approval from the Food and Drug Administration (FDA) and the European Medicines Agency (EMA) for the treatment of patients with advanced pNETs and more recently, for NETs of gastrointestinal or lung origin. However, disease stabilization is observed rather than objective response, which remains low $(<5 \%)$. The modest antitumor activity of everolimus observed in clinical trials may be due to feedback mechanisms favoring prosurvival signals. The loss of S6kinase-dependent negative feedback loop, involving expression of the insulin receptor substrate 1 (IRS-1), leading to the activation of PI3K/Akt and Ras/MAPKinase has been observed in breast cancer cell lines and human breast and colorectal carcinomas after everolimus treatment $[15,16]$. Therefore, combined treatments with drugs targeting PI3K/Akt could improve the anti-proliferative effect of everolimus. In this regard, activation of SST2 has been shown to repress PI3K activity by disrupting the interaction between SST2 and the p85 PI3K regulatory subunit in pituitary and pancreatic adenocarcinoma cell lines $[17,18]$. Clinical benefits of combined everolimus with octreotide have been evaluated in pNETs in a phase II trial. Concomitant treatment of everolimus and octreotide increased PFS in comparison with everolimus alone, however objective response rate was lesser in combined treatment [19].

We have recently established and characterized primary cultures of human pNETs and demonstrated the anti-proliferative effects of both octreotide and pasireotide [20]. To assess the relevance of everolimus and cotreatments in pNETs, we have used this suitable state-ofthe-art preclinical model to evaluate the anti-proliferative and anti-secretory effects of everolimus in single treatment or in combination with the SSAs octreotide and pasireotide from 25 well characterized tumors. The role of PI3K/Akt/ mTOR and the MAPKinase ERK1/2 signaling pathways under these treatments has also been monitored.

\section{RESULTS}

\section{Molecular characteristics of pNET tissues and pNET primary cultures}

Mutations of MEN1, DAXX/ATRX, PTEN or down regulation of their respective proteins have been frequently observed in pNETs $([8,9]$. Loss of DAXX/ ATRX expression has recently been associated with poor prognosis and might be used to refine prognostic classification [21]. PTEN mutations have been associated with rapamycin sensitivity in different cell lines [22]. In this context, to better characterize patients' tumors, we searched for MEN1 mutations from formalin-fixed paraffin-embedded tissue sections (FFPE) (Table 1). PTEN, DAXX and ATRX expression was performed by using immunohistochemistry (IHC) (Table 1). MEN1 mutations were frequently observed in $68 \%$ of the tumors (17/25). PTEN was always found expressed but with varying levels. Low PTEN expression was observed in $28 \%$ of the tumors $(7 / 25)$. ATRX or DAXX expression was lost in $29 \%$ of the tumors (7/24). A similar frequency has been obtained by Singhi et al. in a large series of pNETs [21]. We did not observe any correlation between PTEN, MEN1 and DAXX/ATRX alterations (not shown), 
Table 1: Molecular characteristics of human pNET tissues

\begin{tabular}{|c|c|c|c|c|c|}
\hline $\begin{array}{l}\text { tumor } \\
\text { (number) }\end{array}$ & Grade & MEN1 (tumoral mutation) & PTEN IHC & ATRX IHC & DAXX IHC \\
\hline 1 & G2 & No & 1(h) & $\mathrm{N}$ & $\mathrm{P}$ \\
\hline 2 & G1 & No & 3 & $\mathrm{P}$ & $\mathrm{P}$ \\
\hline 3 & $\mathrm{G} 2$ & exon 10 deleted & 3 & $\mathrm{P}$ & $\mathrm{P}$ \\
\hline 4 & G1 & Exon 4 : c.660G $>A\left(p \cdot T r p 220^{*}\right)$ & 2 & $\mathrm{P}$ & NA \\
\hline $5(a)$ & $\mathrm{G} 2$ & Exon 2 : c.249_252del (p.Ile85Serfs*33) & 2 & $\mathrm{P}$ & $\mathrm{P}$ \\
\hline 6 & G3 & No & $3(\mathrm{~h})$ & $\mathrm{P}$ & $\mathrm{P}$ \\
\hline 7 & G1 & Exon 3 : c.586G>A (p.Val196Ile) & 3 & $\mathrm{P}$ & $\mathrm{P}$ \\
\hline 8 & $\mathrm{G} 2$ & Exon 9 : c.1226G>A (p.Cys409Tyr) & $3(\mathrm{~h})$ & $\mathrm{P}$ & $\mathrm{N}$ \\
\hline 9 & $\mathrm{G} 2$ & Exon 2 : c.244G>C (p.Asp82His) & 2 & $\mathrm{P}$ & $\mathrm{N}$ \\
\hline 10 & $\mathrm{G} 2$ & Exon 5 : c.833T $>$ C (p.Met278Thr) & 3 & $\mathrm{P}$ & $\mathrm{P}$ \\
\hline 11 & G2 & Exon 8 : c.1151A $>$ G p.Glu384Lys & 3 & $\mathrm{P}$ & $\mathrm{P}$ \\
\hline 12 & G2 & Exon 3 : c.456T $>$ G (p.Leu152Phe) & $1(\mathrm{~h})$ & $\mathrm{P}$ & NA \\
\hline 13 & $\mathrm{G} 2$ & No & 3 & $\mathrm{P}$ & $\mathrm{P}$ \\
\hline 14 & G2 & Exon 3 : c.526G $>$ A (p.Ala176Thr) & 2 & $\mathrm{P}$ & $\mathrm{P}$ \\
\hline 15 & G3 & $\begin{array}{l}\text { Exon } 3: \text { c. } 487 \mathrm{G}>\mathrm{A} \text { (p.Gly163Arg) } \\
\text { Exon } 10: \text { c.1741G }>\text { A (p.Ala581Thr) }\end{array}$ & 1 & NA & $\mathrm{N}$ \\
\hline 16 & $\mathrm{G} 2$ & Exon7 : c.1034C $>$ T p.Ala345Val & $1(\mathrm{~h})$ & $\mathrm{P}$ & $\mathrm{P}$ \\
\hline 17 & $\mathrm{G} 2$ & No & 3 & $\mathrm{P}$ & $\mathrm{P}$ \\
\hline 18 & G2 & $\begin{array}{c}\text { Exon 2: c.38T }>C \text { (p.Leu13Pro) } \\
\text { Exon 9: c.1318C }>\mathrm{T} \text { (p.Leu440Phe) }\end{array}$ & 1(h) & NA & NA \\
\hline 19 & G1 & Exon2: c.322C>T (p.Arg108*) & $1(\mathrm{~h})$ & $\mathrm{P}$ & $\mathrm{P}$ \\
\hline 20(a) & G1 & Exon $7 \mathrm{c} .1049 \mathrm{C}>\mathrm{T}$ & $2(\mathrm{~h})$ & $\mathrm{P}$ & $\mathrm{N}$ \\
\hline 21 & G1 & No & 3 & $\mathrm{P}$ & $\mathrm{P}$ \\
\hline 22 & G1 & No & 3 & $\mathrm{P}$ & $\mathrm{P}$ \\
\hline 23 & G3 & $\begin{array}{c}\text { Exon } 2 \text { c. } 244 \mathrm{G}>\mathrm{C} \text { (p.Asp82His) } \\
\text { Exon 3: c.514G }>\text { A (p.Asp172Asn) }\end{array}$ & 3 & $\mathrm{P}$ & $\mathrm{N}$ \\
\hline 24 & G3 & Exon 3 : c.514G>A (p.Asp172Asn) & $1(\mathrm{~h})$ & $\mathrm{N}$ & $\mathrm{P}$ \\
\hline 25 & G2 & No & 2 & NA & $\mathrm{P}$ \\
\hline
\end{tabular}

IHC (immunohistochemistry). (a) MEN1 syndrome, mutation found at the germinal level and in the tumor. (h)

Heterogeneous labeling. 1-3: low to high labeling level. N (negative labeling). P (positive labeling). NA (not available).

neither between DAXX/ATRX loss and the initial grade of the tumor $(\mathrm{p}=0.093)$. However, DAXX/ATRX was lost in 3 out of the 4 grade 3 tumors present in our series (Table 1).

We have previously shown that pNET cells in primary culture maintained their neuroendocrine characteristics. In particular, the majority of cells expressed chromogranin A (CgA) and the SST2 receptor. Moreover we observed that their capacity to secrete $\mathrm{CgA}$ was regulated by SSAs [20]. Thus we determined the level of SST2 mRNA expression, CgA secretion and its sensitivity to octreotide in the primary cultures of our series (Table 2). We detected SST2 mRNA expression in all the primary culture analyzed. As previously observed SST2 expression level was higher than the other SST subtypes (not shown). We detected CgA secretion in all investigated primary cultures with variable levels. Moreover, except in one primary culture (tumor 2), $\mathrm{CgA}$ secretion was significantly decreased by $1 \mathrm{nM}$ octreotide (Table 2). 
Table 2: Molecular characteristics of pNET primary cultures

\begin{tabular}{|c|c|c|c|c|}
\hline \multirow[t]{2}{*}{ Tumor (number) } & \multirow[t]{2}{*}{ Grade } & \multirow{2}{*}{$\begin{array}{l}\text { SST2R (copies/ } \\
\text { copies GUS } \beta \text { ) }\end{array}$} & \multicolumn{2}{|c|}{ CgA secretion } \\
\hline & & & Control (U/l) & octreotide (\%inhibition) \\
\hline 1 & $\mathrm{G} 2$ & 2.80 & $325 \pm 9$ & $28 \pm 1 * *$ \\
\hline 2 & G1 & 4.94 & $170 \pm 5$ & $8 \pm 5$ \\
\hline 3 & $\mathrm{G} 2$ & 1.57 & $159 \pm 1$ & $49 \pm 10^{*}$ \\
\hline 4 & G1 & 6.67 & $3941 \pm 13$ & $51 \pm 4 * *$ \\
\hline 5 & $\mathrm{G} 2$ & ND & ND & ND \\
\hline 6 & G3 & 0.32 & $10 \pm 1$ & $44 \pm 7^{*}$ \\
\hline 7 & G1 & 5.08 & $137 \pm 6$ & $93 \pm 1 * * *$ \\
\hline 8 & G2 & 0.96 & $49 \pm 1$ & $34 \pm 11 *$ \\
\hline 9 & G2 & 1.62 & $40 \pm 2$ & $39 \pm 2 * *$ \\
\hline 10 & $\mathrm{G} 2$ & 0.50 & $488 \pm 10$ & $72 \pm 1^{*}$ \\
\hline 11 & $\mathrm{G} 2$ & 0.53 & $21 \pm 2$ & $37 \pm 6^{*}$ \\
\hline 12 & $\mathrm{G} 2$ & 2.23 & $514 \pm 11$ & $71 \pm 1 * * *$ \\
\hline 13 & G2 & 0.88 & $870 \pm 125$ & $63 \pm 2^{* *}$ \\
\hline 14 & $\mathrm{G} 2$ & 2.75 & $569 \pm 48$ & $16 \pm 2 *$ \\
\hline 15 & G3 & 7.62 & $284 \pm 13$ & $93 \pm 2 * *$ \\
\hline 16 & G2 & 0.96 & $691 \pm 87$ & $76 \pm 10^{*}$ \\
\hline 17 & G2 & 3.65 & $93 \pm 19$ & $47 \pm 6^{*}$ \\
\hline 18 & $\mathrm{G} 2$ & 3.94 & $66 \pm 2$ & $36 \pm 4 * *$ \\
\hline 19 & G1 & 2.35 & $735 \pm 33$ & $36 \pm 15^{*}$ \\
\hline 20 & G1 & ND & ND & ND \\
\hline 21 & G1 & 3.23 & $16 \pm 2$ & $49 \pm 9^{*}$ \\
\hline 22 & G1 & 2.67 & $568 \pm 21$ & $85 \pm 1 * * *$ \\
\hline 23 & G3 & 1.11 & ND & ND \\
\hline 24 & G3 & 0.50 & ND & ND \\
\hline 25 & G2 & 6.92 & ND & ND \\
\hline
\end{tabular}

SST2 receptor mRNA was determined as described in patients and methods by real-time PCR. Cells were treated in the absence or in the presence of $1 \mathrm{nM}$ octreotide and $\mathrm{CgA}$ secretion was measured as described in patients and methods. $(*)$ $\mathrm{p}<0.05 ;(* *) \mathrm{p}<0.01(* * *) \mathrm{p}<0.001$ versus control conditions.

\section{Effects of everolimus on cell viability}

We first examined a dose effect of everolimus treatment for $72 \mathrm{~h}$ ranging from $0.1 \mathrm{nM}$ to $10 \mathrm{nM}$ on cell viability of 3 pNETs primary cultures. Everolimus significantly reduced viable cell number at both 1 and $10 \mathrm{nM}$ with maximal effect observed for 1nM (Figure 1A). We then tested the effect of $1 \mathrm{nM}$ everolimus during $72 \mathrm{~h}$, in the primary cultures from $22 \mathrm{pNETs}$. This concentration is approximately the blood concentration of everolimus (range 2.7-95 nM) measured after $24 \mathrm{~h}$ treatment of patients with 5-10mg per day [23, 24]. Everolimus decreased viable cell number from $14 \%$ to $77 \%$ of control value in 20 primary cultures (Figure 1B) with a median value of $59.3 \%$ (Figure 1C). Cell viability was not significantly altered in 2 primary cultures $(90 \pm 12 \%$ of control value; Figure 1B). No correlation was observed between cell viability inhibition by everolimus and the WHO grade or Ki67 index of the initial tumor $(\mathrm{R}=-0.207$, $\mathrm{p}=0.355 ; \mathrm{R}=-0.122, \mathrm{p}=0.590$ respectively). However, cell viability was repressed from 40 to $58 \%$ by everolimus in 4 out of 6 tested tumors with a Ki67 $\geq 10 \%$ (two grade 3 
A
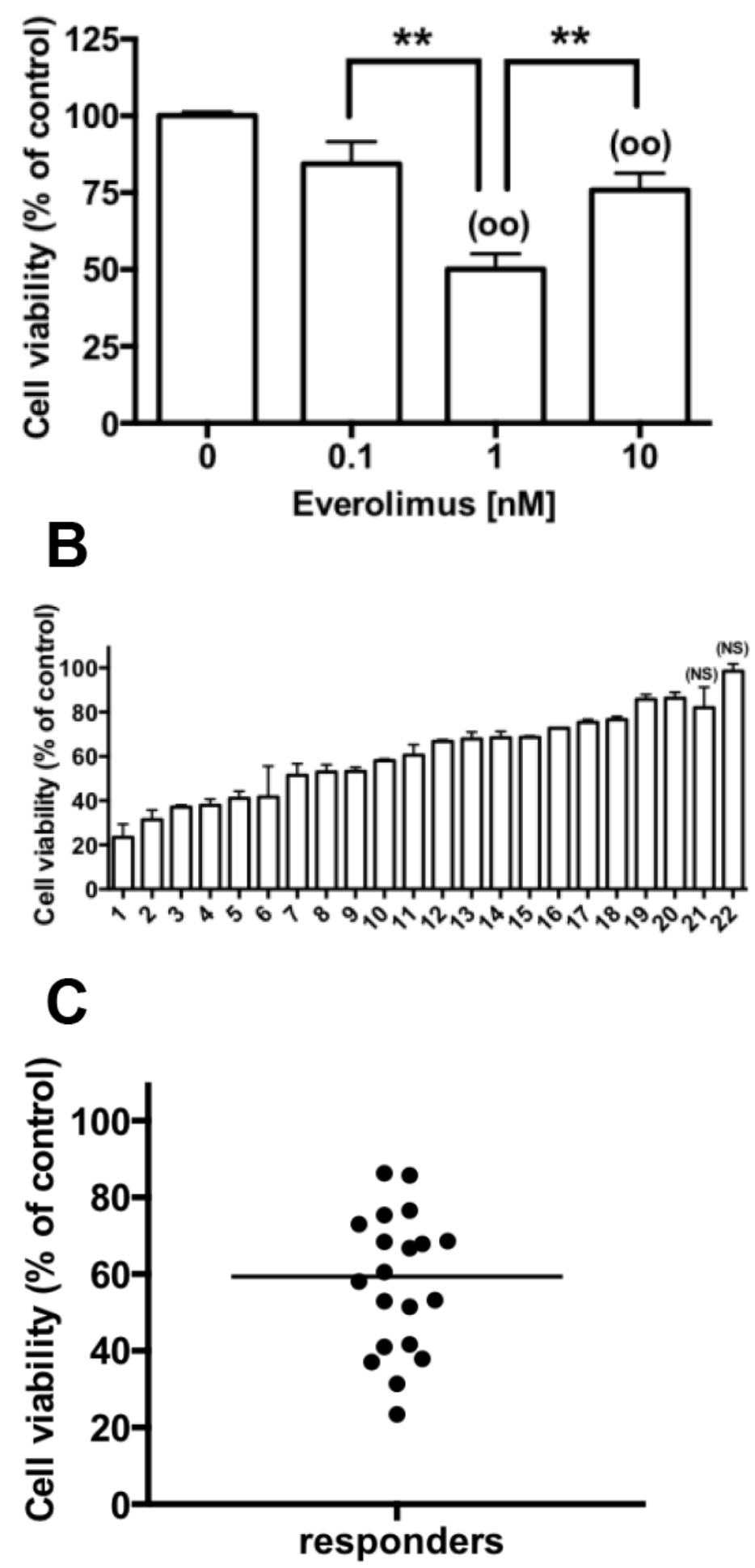

Figure 1: Everolimus decreases cell viability in primary cultures of human pNETs. (A) Primary culture cells from 3 pNETs (tumors 2,10,11) were incubated without (vehicle with $10^{6}$ fold DMSO dilution) and with 0.1-10 nM everolimus for $72 \mathrm{~h}$ and cell viability was determined as described in patients and methods. Results are expressed as mean \pm SEM $(n=3)$ in percent of control. Each assay was performed in triplicate. $\left({ }^{* *}\right) \mathrm{p}<0.01 ;\left({ }^{\circ}\right) \mathrm{p}<0.01$ versus control. (B) Cell viability determined as in A in primary culture cells from 22 pNETs incubated without (vehicle) and with $1 \mathrm{nM}$ everolimus for $72 \mathrm{~h}$. (NS = not significant). (C) Cell viability determined in B in the primary cultures of the 20 pNETs responsive to $1 \mathrm{nM}$ everolimus. The horizontal bar represents the median. 
with $\mathrm{Ki} 67 \geq 45 \%$ ). In the same way, no correlation was observed between cell viability inhibition by everolimus and the presence of MEN1 tumor mutations or PTEN, DAXX/ATRX expression levels.

\section{Effects of everolimus on $\mathrm{CgA}$ secretion}

In the same 3 pNETs primary cultures described above, everolimus significantly decreased $\mathrm{CgA}$ secretion with the same efficacy regardless the concentration (Figure 2A). Among the 19 primary cultures analyzed, $1 \mathrm{nM}$ everolimus reduced $\mathrm{CgA}$ secretion from $13 \%$ to $61 \%$ of the control value in 12 primary cultures of pNETs with a median value of $43.3 \%$ (Figure $2 \mathrm{~B}, 2 \mathrm{C}$ ). CgA secretion was not significantly modified under $1 \mathrm{nM}$ everolimus treatment in the primary cultures from 7 tumors (median value $=92.2 \%$ of control) (Figure 2B, 2C). There was no correlation between everolimus inhibitions observed on cell viability and on $\mathrm{CgA}$ secretion $(\mathrm{R}=0.036, \mathrm{p}=0.883)$. No correlation was observed between the inhibition of $\mathrm{CgA}$ secretion by everolimus and the WHO grade or Ki67 index of the initial tumor $(\mathrm{R}=0.237, \mathrm{p}=0.328$; $\mathrm{R}=0.134$, $\mathrm{p}=0.584$ respectively). However, $\mathrm{CgA}$ secretion was repressed from 37 to $69 \%$ by everolimus in 4 out of 5 tested tumors with a $\mathrm{Ki} 67 \geq 10 \%$ (two grade 3 with Ki67 $\geq$ $45 \%$ ). Moreover, no correlation was observed between $\mathrm{CgA}$ inhibition by everolimus and the presence of MEN1 tumor mutations or PTEN, DAXX/ATRX expression levels.

\section{Effects of everolimus and SSAs in combination, on cell viability and caspase activities}

We have previously shown that, at clinically relevant concentrations $[25,26]$, both octreotide and pasireotide repressed hormonal secretion and cell viability in established pNETs primary cultures [20]. We then tested combined treatment of everolimus and SSAs, on cell viability in 19 pNETs responsive to everolimus in primary cultures. As previously described [20], 72h exposure to $1 \mathrm{nM}$ octreotide or $1 \mathrm{nM}$ pasireotide reduced cell viability with no significant difference between both analogs (Figure 3A, 3B, 3C). We have previously shown a strong correlation between the effects of octreotide and pasireotide on cell viability. A slight correlation was observed between everolimus and octreotide effects on cell viability whereas no correlation was observed between everolimus and pasireotide $(\mathrm{R}=0.492, \mathrm{p}=0.044$; $\mathrm{R}=0.217, \mathrm{p}=0.402$ respectively). No significant correlation was observed between the inhibition of cell viability by each SSA and the WHO grade or Ki67 index of the initial tumor $(\mathrm{R}<0.07, \mathrm{p}>0.786$ in the different cases $)$. However, cell viability was largely repressed by octreotide, in 2 out of 5 tested tumors with a $\mathrm{Ki} 67 \geq 10 \%$ (by $53 \%$ in a grade 2 tumor with a $\mathrm{Ki} 67=10 \%$ and by $74 \%$ in a grade 3 tumor with $\mathrm{Ki} 67=90 \%$ ). We did not observed any correlation between SSAs-induced cell viability inhibition and the presence of MEN1 tumor mutations or PTEN, DAXX/ ATRX expression levels.

Cells from the different pNETs did not respond similarly to combined treatments of $1 \mathrm{nM}$ everolimus with either $1 \mathrm{nM}$ octreotide or $1 \mathrm{nM}$ pasireotide. Everolimusinduced inhibition of cell viability was increased in only one primary culture (from a grade 2 tumor with $\mathrm{Ki} 67=3 \%$; tumor $\mathrm{n}^{\circ} 8$ ) under combined treatments (Figure 3A). Two types of response were observed for the other 18 primary cultures. Cell viability was significantly inhibited whatever the treatment in 9 primary cultures, without significant difference between the different treatments, even in combination (Figure 3B). These primary cultures were from 2 grade 1 and 7 grade 2 tumors, with Ki67 $\geq 5 \%$ in 6 tumors. Cell viability was also significantly inhibited by single treatments in the remaining 9 primary cultures with a significantly higher sensitivity to everolimus than SSAs ( $p=0.02$ and $p=0.004$ respectively for octreotide and pasireotide). Surprisingly, combined treatments of $1 \mathrm{nM}$ everolimus with either $1 \mathrm{nM}$ octreotide or $1 \mathrm{nM}$ pasireotide, in these primary cultures, partially or fully reversed inhibition of cell viability induced by each single treatment (Figure 3C). Moreover, primary cultures of this group (Figure 3C) are significantly more responsive to everolimus than primary cultures responding similarly to each treatment (Figure $3 \mathrm{~B})(\mathrm{p}<0.02)$. These primary cultures were from 3 grade 1, 4 grade 2 and 2 grade 3 tumors with $\mathrm{Ki} 67 \geq 5 \%$ in 5 tumors. There was no significant difference between the two type of response to combined treatments with respect to the grade or Ki67 index of the initial tumor ( $\mathrm{p}=0.999, \mathrm{p}=0.746$ respectively).

To elucidate the observed effects of everolimus alone or in combined treatment with the SSAs on cell viability, we determined the activation level of the executioner caspases 3/7. Basal caspase activities were not modified with $1 \mathrm{nM}$ everolimus treatment during $24 \mathrm{~h}$ whereas both $1 \mathrm{nM}$ octreotide and $1 \mathrm{nM}$ pasireotide significantly increased caspase activities as previously observed associated to an increase in the number of TUNEL positive cells ([20], Figure 3D). Caspase activities were not significantly triggered by combined treatments of $1 \mathrm{nM}$ everolimus with either $1 \mathrm{nM}$ octreotide or with $1 \mathrm{nM}$ pasireotide (Figure 3D). This suggests that everolimus repressed the activity of caspases induced by SSAs in single treatments. Caspase activities have been determined in 6 primary cultures. Five of them belong to primary cultures described in Figure $3 \mathrm{C}$ and one in Figure 3B without difference in the response.

\section{Effects of everolimus and SSAs in combination on CgA secretion}

We next explored the effect of everolimus combined with the SSAs on CgA secretion from the 12 pNETs responsive to everolimus in primary cultures. $72 \mathrm{~h}$ 

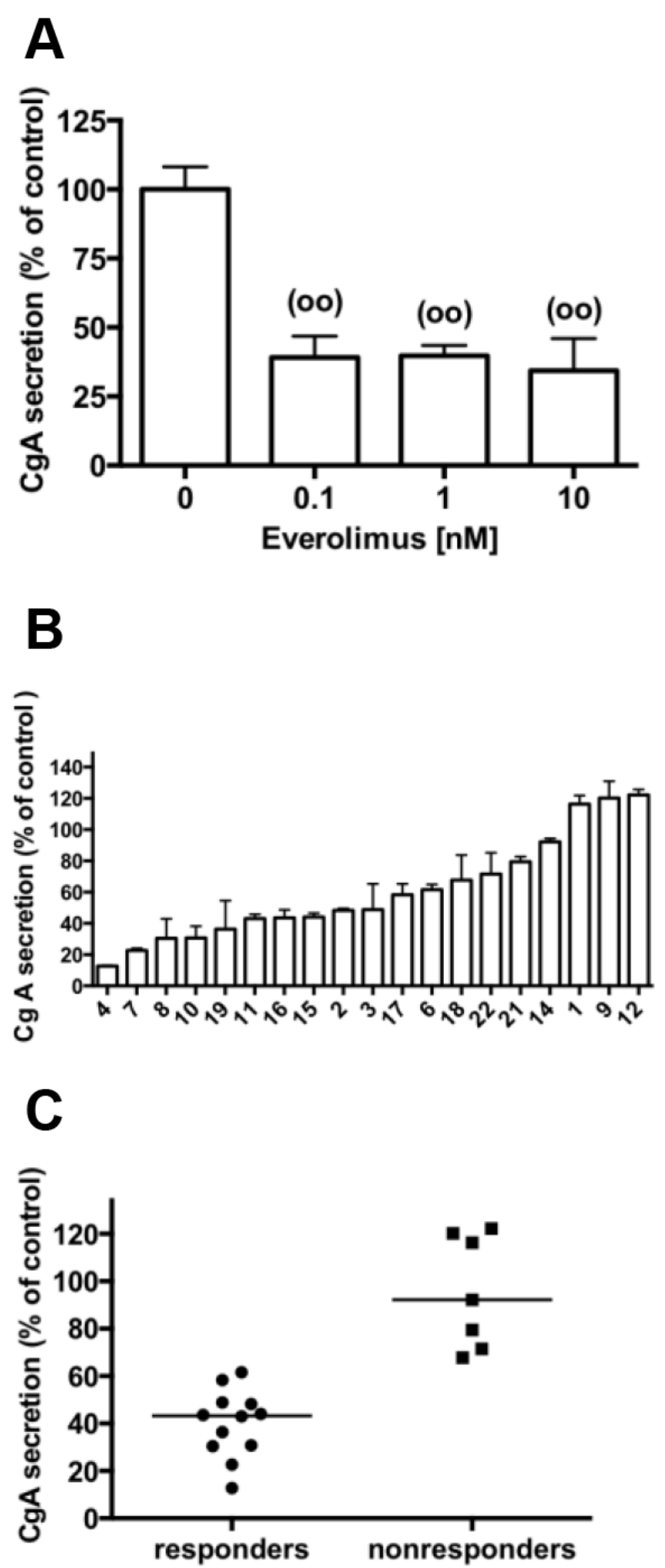

Figure 2: Effect of everolimus on CgA secretion in primary cultures of human pNETs. (A) Primary culture cells from 3 pNETs (tumors 2,10,11) were incubated without (vehicle with $10^{6}$ fold DMSO dilution) and with 0.1-10 nM everolimus for $72 \mathrm{~h}$ and CgA secretion was measured as described in patients and methods. Results are expressed as mean \pm SEM ( $\mathrm{n}=3$ ) in percent of control. Each assay was performed in triplicate. $\left({ }^{\circ \circ}\right) \mathrm{p}<0.01$ versus control. (B) CgA secretion determined as in A in primary culture cells from $19 \mathrm{pNETs}$ incubated without (vehicle) and with $1 \mathrm{nM}$ everolimus for $72 \mathrm{~h}$. (C) CgA secretion determined in B of the 12 pNETs primary cultures that were responsive to $1 \mathrm{nM}$ everolimus treatment and $\mathrm{CgA}$ secretion of the 7 pNETs primary cultures that were nonresponsive to everolimus treatment. The horizontal bars represent the medians. 
treatment of cells with $1 \mathrm{nM}$ octreotide or $1 \mathrm{nM}$ pasireotide alone similarly decreased $\mathrm{CgA}$ secretion as previously observed [20] (Figure 4A, 4B), except in one primary culture which do not respond to SSAs (tumor 2; Table 2). We did not observe any correlation between everolimus and octreotide or everolimus and pasireotide inhibition of CgA secretion $(\mathrm{R}=0.205, \mathrm{p}=0.522 ; \mathrm{R}=0.342, \mathrm{p}=0.276$ respectively). Inhibition of $\mathrm{CgA}$ secretion by combined treatments was increased in only one primary culture (from a grade 1 tumor, with $\mathrm{Ki} 67<2 \%$; tumor 4 ) in comparison to everolimus or SSAs treatments alone (Figure 4A). We noticed that in this primary culture, combined treatments partially reverted cell viability inhibition induced by each single treatment. CgA secretion was significantly inhibited in the other 10 primary cultures whatever the treatment (Figure 4B). However no significant difference was observed between the different treatments, even in the combined treatments of $1 \mathrm{nM}$ everolimus with $1 \mathrm{nM}$ octreotide or $1 \mathrm{nM}$ pasireotide (Figure 4B). These 10 primary cultures were from 2 grade 1,6 grade 2 and 2 grade 3 tumors with $\mathrm{Ki} 67 \geq 5 \%$ in 7 tumors. We did not observe any correlation between tumor grade, Ki67 index, MEN1 tumor mutations or PTEN, DAXX/ATRX expression levels of the initial tumor and inhibition of $\mathrm{CgA}$ secretion by the different treatments $(\mathrm{R}<0.156, \mathrm{p}>0.109)$. These results suggested that although everolimus and SSAs reduced cell viability and $\mathrm{CgA}$ secretion in single treatments, treatment combinations did not achieve any beneficial impact except in two tumors $(4,8)$.

\section{Modulation of PI3K/Akt and ERK1/2 pathways under everolimus and SSAs single treatments}

It has been shown, in neuroendocrine cell lines or tumors, that everolimus and SSAs might control cell proliferation through the modulation of the PI3K/Akt/ mTOR and/or the MAPKinase ERK1/2 pathways. In this context, we first explored the phosphorylated level
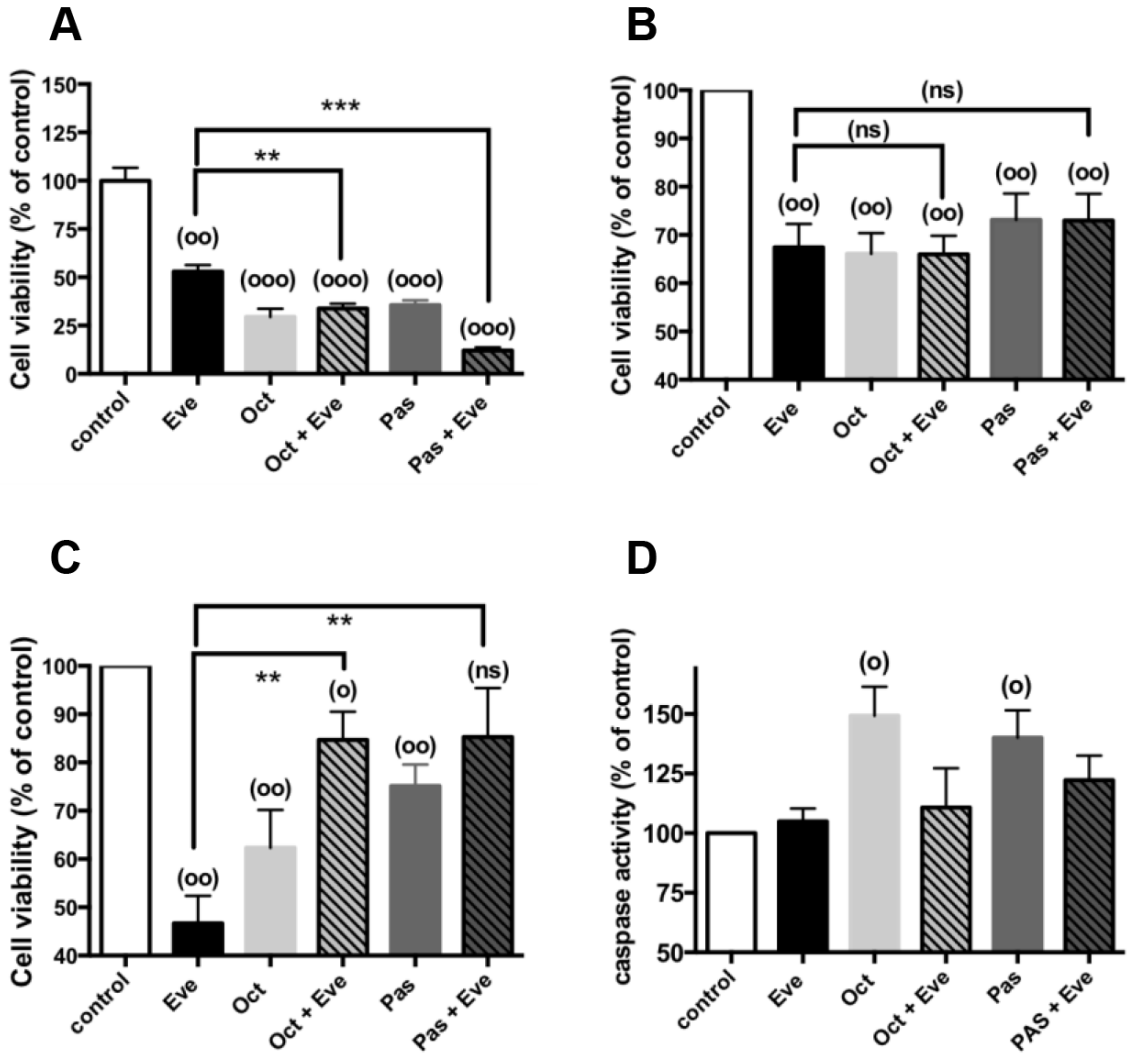

Figure 3: Cell viability and caspase activities in combined treatments of everolimus with SSAs. Primary culture cells from (A) one pNET (n 8), (B) 9 pNETs $\left(\mathrm{N}^{\circ} 5,10-14,18-20\right)$ (C) 9 pNETs $\left(\mathrm{n}^{\circ} 1-4,6,7,9,15,17\right)$ were incubated for $72 \mathrm{~h}$ in the absence (vehicle) or in the presence of $1 \mathrm{nM}$ everolimus (Eve), or $1 \mathrm{nM}$ octreotide (Oct), or $1 \mathrm{nM}$ pasireotide (Pas) alone (diluted in vehicle) or in the presence of everolimus and octreotide or everolimus and pasireotide as indicated in the figure. Cell viability was determined as described in patients and methods. Results are expressed as mean $\pm \operatorname{SEM}((\mathbf{A}), n=1 ;(\mathbf{B}, \mathbf{C}) \mathrm{n}=9)$ in percent of control. (D) Primary cultures from 6 pNETs $\left(\mathrm{n}^{\circ} 1\right.$ $3,7,9,18$ ) were incubated for $24 \mathrm{~h}$ in the absence (vehicle) or in the presence of $1 \mathrm{nM}$ everolimus and/or SSAs (diluted in vehicle) as indicated in the figure. Caspase activity was determined as described in patients and methods. Results are expressed as mean $\pm \mathrm{SEM}(\mathrm{n}=6)$ in percent of control. Each assay was performed in triplicate. $\left({ }^{\circ}\right) \mathrm{p}<0.05 ;\left({ }^{\circ}\right) \mathrm{p}<0.01\left({ }^{\circ \circ}\right) \mathrm{p}<0.001$ versus control; $\left({ }^{* *}\right) \mathrm{p}<0.01 ;(* * *) \mathrm{p}<0.001,(n s)$ not significant. 
of key intermediates of both pathways under everolimus and SSAs single treatments. We assessed the effect of everolimus, inhibitor of mTORC1, on its downstream target phosphorylation, p70S6K. After $30 \mathrm{~min}$ and $24 \mathrm{~h}$ of treatment with $1 \mathrm{nM}$ everolimus, p70S6K phosphorylation was largely decreased, confirming that pNETs cells in primary cultures are sensitive to everolimus (Figure 5A, 5B). In these conditions, Akt phosphorylation was not modified during short treatment (30min), whereas it was increased after $24 \mathrm{~h}$ of treatment (Figure 5A, 5B). Noted that although phospho-p70S6K was repressed, phospho-
Akt (P-Akt) was not increased after $24 \mathrm{~h}$ of everolimus treatment in two of the seven pNETs analyzed (tumors 5, 20). In addition, $1 \mathrm{nM}$ everolimus treatment did not alter ERK1/2 phosphorylation even after $24 \mathrm{~h}$ of treatment (Figure 5A, 5B). Similarly, treatment of pNETs in primary cultures with $1 \mathrm{nM}$ octreotide or $1 \mathrm{nM}$ pasireotide during $30 \mathrm{~min}$ or $24 \mathrm{~h}$ did not significantly modify the phosphorylation levels of p70S6K, Akt or ERK1/2 (Figure $5 \mathrm{C}-5 \mathrm{~F})$. These results suggested that the SSAs did not modulate the activity of PI3K/Akt and ERK1/2 pathways in our experimental conditions.
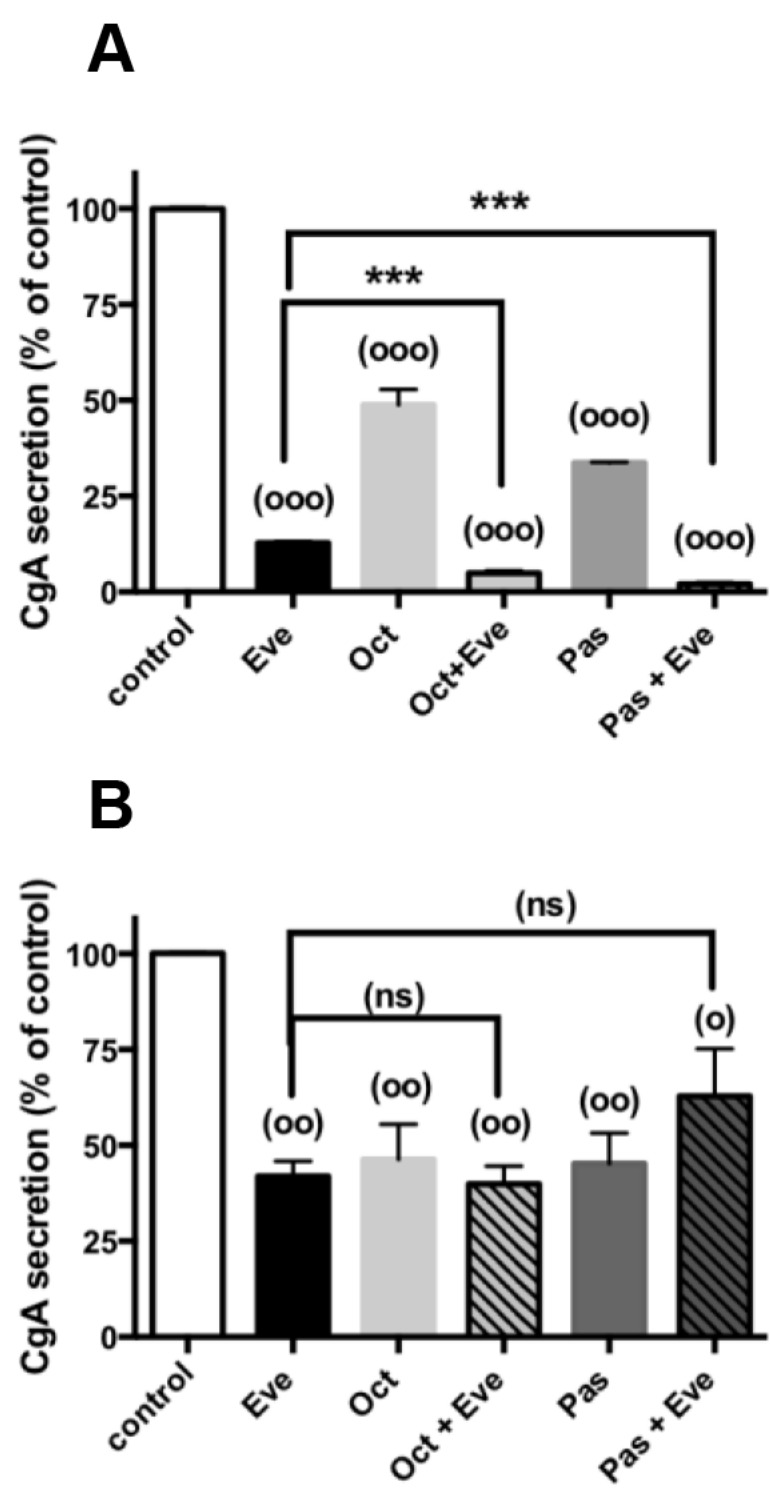

Figure 4: CgA secretion in combined treatments of everolimus with SSAs. Primary culture cells from (A) one pNET ( $\left.{ }^{\circ} 4\right)$, (B) 10 pNETs $\left(\mathrm{n}^{\circ} 3,6-8,10,11,15-17,19\right)$ were incubated for $72 \mathrm{~h}$ in the absence (vehicle) or in the presence of 1nM everolimus (Eve), or $1 \mathrm{nM}$ octreotide (Oct), or 1nM pasireotide (Pas) alone (diluted in vehicle) or in the presence of everolimus and octreotide or everolimus and pasireotide as indicated in the figure. $\mathrm{CgA}$ secretion was determined as described in patients and methods. Results are expressed as mean \pm $\operatorname{SEM}((\mathbf{A}) \mathrm{n}=1 ;(\mathbf{B}) \mathrm{n}=10)$ in percent of control. Each assay was performed in triplicate. $\left({ }^{\circ}\right) \mathrm{p}<0.05 ;\left({ }^{\circ}\right) \mathrm{p}<0.01\left({ }^{\circ \circ \circ}\right) \mathrm{p}<0.001$ versus control $;(* * *) \mathrm{p}<0.001,(\mathrm{~ns})$ not significant. 


\section{Effects of everolimus and SSAs in combined treatments on PI3K/Akt and ERK1/2 pathways}

We finally assessed the effects of combined everolimus and SSAs treatments on PI3K/Akt and ERK1/2 pathways. Combined treatments of $1 \mathrm{nM}$ everolimus and $1 \mathrm{nM}$ octreotide or $1 \mathrm{nM}$ pasireotide during $24 \mathrm{~h}$ significantly inhibited p70S6K phosphorylation compared to control or SSAs in single treatment. However, SSAs did not enhance everolimus-induced inhibition of p70S6K phosphorylation $(p=0.125 ; p=0.875$ respectively in the presence of octreotide plus everolimus and pasireotide plus everolimus; Figure 6A, 6B). Likewise, combined treatments significantly increased P-Akt compared to control conditions or SSAs in single treatment (Figure 6A, 6C). However, P-Akt level was similar in both everolimus as single treatment or in combined treatments $(p=0.796 ; p=0.750$ respectively in the presence of octreotide plus everolimus and pasireotide plus everolimus). In the same conditions, drugs combination did not alter ERK1/2 phosphorylation (Figure 6A, 6D) as previously observed in the presence of each drug alone (Figure 5).

\section{DISCUSSION}

Therapeutic strategy in the management of advanced pNETs is still challenging. Despite promising efficacy of targeted therapies observed in cell lines, PFS and overall survival of patients in clinical trials are lower than

\section{A}

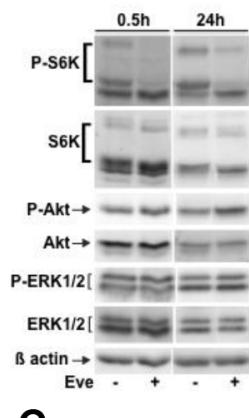

C

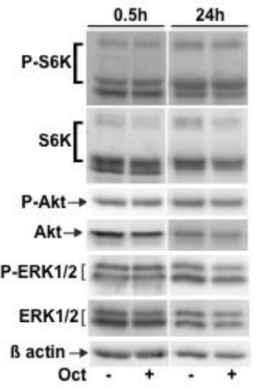

$\mathbf{E}$

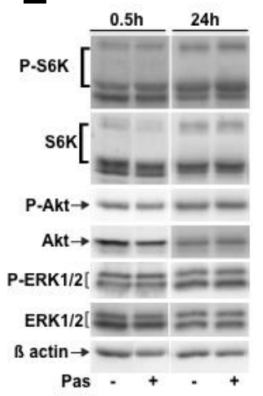

B

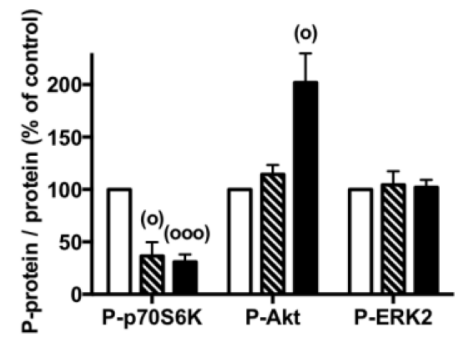

D
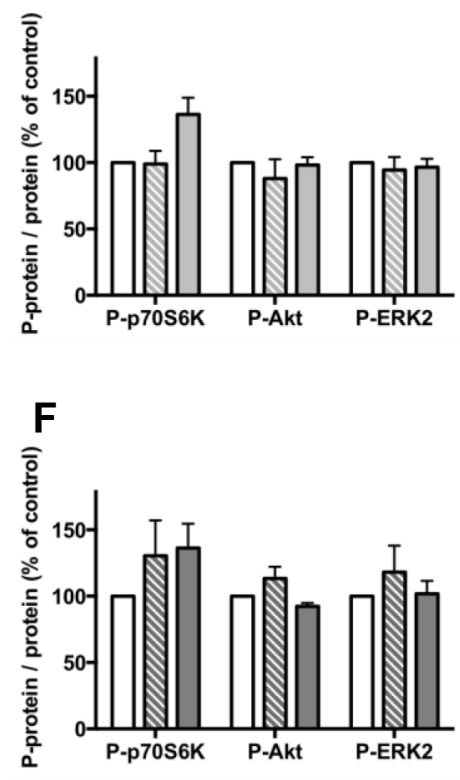

Figure 5: Effects of everolimus and the SSAs single treatments on the activity of the PI3K/Akt and MAPKinase ERK1/2 pathways. Primary culture cells from pNETs were incubated $30 \mathrm{~min}$ ( 3 pNETs) or $24 \mathrm{~h}$ in the absence (vehicle) or in the presence of $1 \mathrm{nM}$ everolimus (Eve) (7 pNETs) (A, B) or 1nM octreotide (Oct) (5 pNETs) (C, D) or 1nM pasireotide (Pas) (5 pNETs) (E, F). The phosphorylated levels of p70S6K, Akt and ERK1/2 were analyzed by using western blotting as described in patients and methods. Representative immunoblots are given in (A), (C), (E). Means \pm SEM in percent of control are given in (B), (D), (F) $(\mathbf{( B )} n=7 ;(\mathbf{D}, \mathbf{F})$ $\mathrm{n}=5$ ). Control condition (white bars), 30min treatment (hatched bars), 24h treatment (black and grey bars). $\left(\left(^{\circ}\right) \mathrm{p}<0.05,\left({ }^{\circ}{ }^{\circ \circ}\right) \mathrm{p}<0.001 \mathrm{versus}\right.$ control. 
expected, suggesting lack of relevant preclinical models. We recently established and characterized primary cultures of human pNETs and demonstrated the anti-secretory and anti-proliferative effects of both octreotide and pasireotide [20]. In this report, we show for the first time that the mTOR inhibitor everolimus reduces both $\mathrm{CgA}$ secretion and cell viability in human primary cultures from pNETs. Although everolimus and SSAs decrease cell viability and $\mathrm{CgA}$ secretion in single treatments, no benefit is observed from combined treatments. To further delineate the mechanisms contributing to these effects, we demonstrate that everolimus-induced decrease of cell viability is not due to caspase-dependent apoptosis. Moreover, in combined treatments, caspase activities induced by SSAs are reverted. Considering two main signaling pathways previously shown as involved in NETs tumorigenesis [27], we show that ERK $1 / 2$ pathway is not affected by everolimus or SSAs as single or combined treatments in pNETs primary cultures. However, everolimus hyperactivates Akt, whereas SSAs do not alter PI3K/ $\mathrm{Akt} / \mathrm{mTOR}$ pathway. Moreover, in combined treatments,
p70S6K activity is inhibited and Akt is as much activated as in the presence of everolimus alone.

The anti-proliferative effect of everolimus has been largely established in different NET cell lines [28-30] and particularly of pancreatic origin $[13,31,32]$. For the first time, we show that everolimus represses cell viability in the majority $(90 \%)$ of primary cultures from human pNETs. The efficacy of everolimus is nevertheless variable and may correlate with the observations of the phase II and III clinical trials $[14,19]$ showing that partial or overall responses were rarely observed despite increase in PFS.

Beside the antitumoral management, control of hormone hypersecretion is required for up to $30 \%$ of patients with pNET. Advances in the control of hormoneexcess state have been recently reviewed [33]. Whereas somatostatin analogs are the first-line treatment in the majority of GEP-NET patients, everolimus has been shown effective at controlling hormone-excess symptoms in patients with insulinoma in case reports or in small series [34-37] and in patients with carcinoid syndrome [38]. In clinical trials, $\mathrm{CgA}$ blood level is commonly

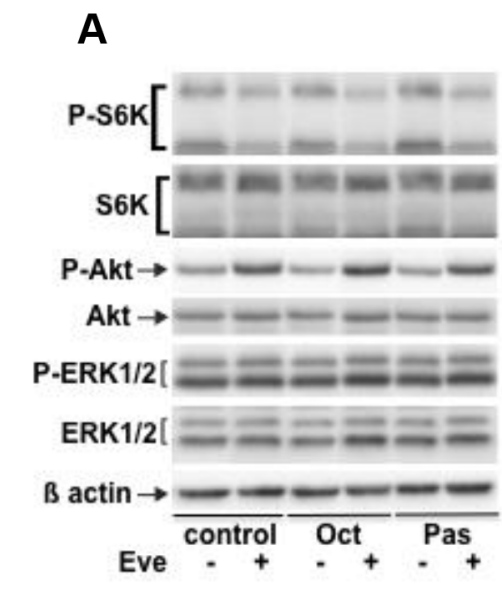

B
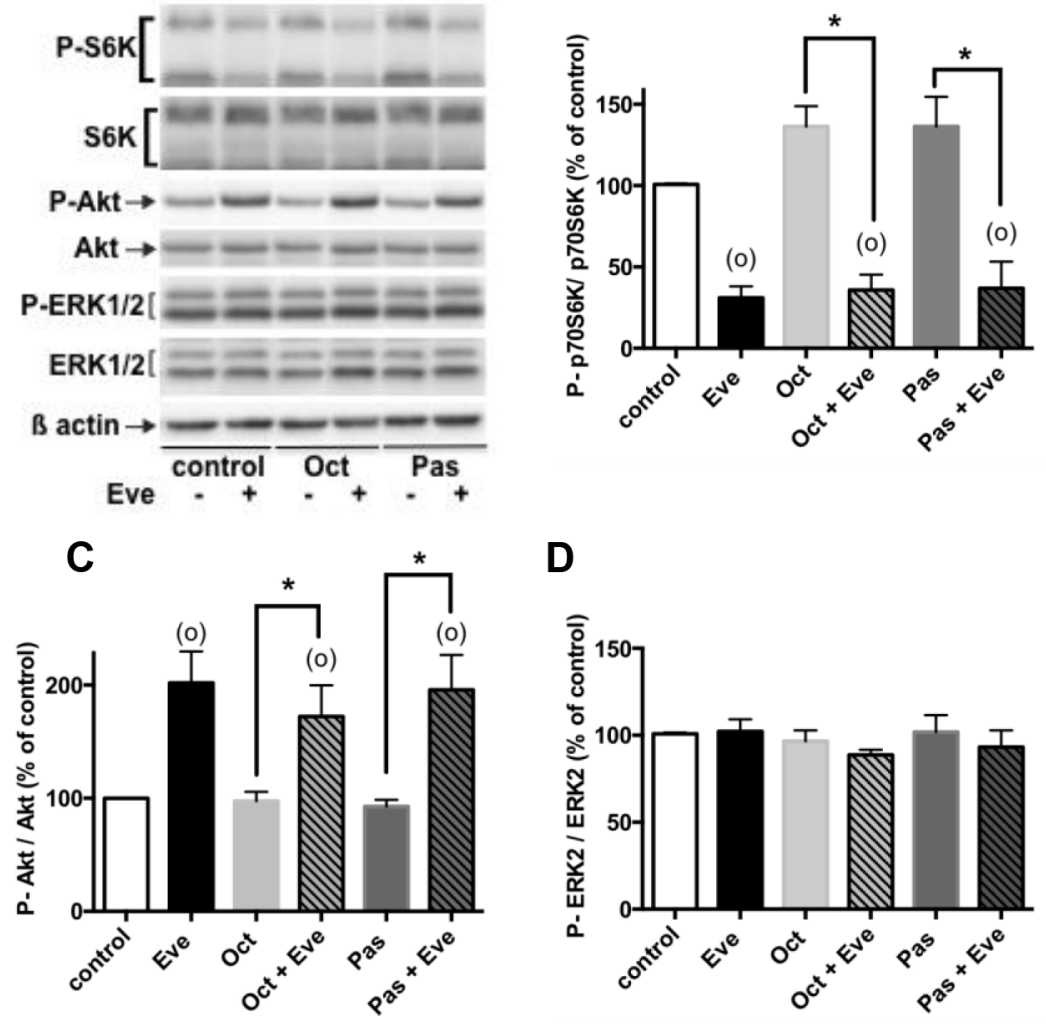

Figure 6: Effects of everolimus and the SSAs in combined treatments on the activity of the PI3K/Akt and MAPKinase ERK1/2 pathways. Primary culture cells from 4 pNETs were incubated for $24 \mathrm{~h}$ in the absence (vehicle) or in the presence of $1 \mathrm{nM}$ everolimus (Eve), or 1nM octreotide (Oct), or 1nM pasireotide (Pas) alone (diluted in vehicle) or in the presence of $1 \mathrm{nM}$ everolimus and $1 \mathrm{nM}$ octreotide or $1 \mathrm{nM}$ everolimus and $1 \mathrm{nM}$ pasireotide as indicated in the figure. The phosphorylated levels of p70S6K, Akt and ERK1/2 were analyzed by using western blotting as described in patients and methods. Representative immunoblots are given in (A). Means \pm SEM $(n=4)$ in percent of control are given for p70S6K (B), Akt (C) and ERK2 (D). $\left(^{*}\right) p<0.05 ;\left(^{\circ}\right) p<0.05$ versus control. 
considered as a biomarker of NETs. An early decrease in $\mathrm{CgA}$ blood level in response to everolimus has been correlated with an increase in PFS. So this early $\mathrm{CgA}$ response might have a global predictive value [19]. Here we show that everolimus represses $\mathrm{CgA}$ secretion in $63 \%$ of the pNETs primary cultures. Since decrease in cell number by everolimus treatment should have an impact on $\mathrm{CgA}$ secretion, the level of $\mathrm{CgA}$ secretion has been normalized to the cell number. Moreover, there is no correlation between everolimus-induced inhibition of cell viability and $\mathrm{CgA}$ secretion, suggesting that everolimus inhibition of $\mathrm{CgA}$ secretion might be a direct effect on pNET cell secretion. The PI3K pathway has been identified as a potential regulator of peptide secretion in the pNET cell lines BON and QGP1 depending on the inhibitor used (PIK-75, BKM120 or BEZ235) and the peptide secreted (neurotensin, serotonin or CgA) [39, 40]. Inhibition of both PI3K and mTOR seems to be required to block peptide secretion [40]. In the primary cultures of pNETs, inhibition of mTOR seems to be sufficient to repress $\mathrm{CgA}$ secretion (see below). Inhibition of $\mathrm{CgA}$ secretion under everolimus treatment is of importance as it has been previously shown that $\mathrm{CgA}$ and some of its fragments induce cell proliferation of the small intestinal NET cell lines L-STS and H-STS through Akt/mTOR activation [41].

Akt activation following rapalogs treatments is commonly observed in cancer cells. This effect has been attributed to loss of physiological negative feedback loops on PI3K/Akt and MAPK pathways, limiting the anti-proliferative potential of these drugs $[15,16,18]$. Activation of Akt by rapalogs is not systematically observed in NET cell lines [13, 30-32]. In the present report, all pNETs primary cultures tested are sensitive to everolimus (using p70S6K inhibition as downstream marker of mTOR inhibition). P-Akt (ser473) is increased whereas activation of ERK $1 / 2$ is never observed. We noticed that P-Akt is not upregulated in two tumors (5, 20). These observations indicate a specific upregulation of the PI3K/Akt pathway through loss of P70S6K/IRS-1 or P70S6K/mTORC2 negative feedbacks $[15,42]$. In these conditions, everolimus does not induce caspase activity. This suggests that proapoptotic substrates downstream of both Akt and p70S6K, may be selectively phosphorylated and inactivated by Akt [43, 44]. Our results are in agreement with those of Valentino et al., showing an inverse correlation between Akt activation and apoptosis in BON and QGP1 cell lines [40]. Whereas everolimus induced both apoptosis and cell cycle arrest in cell lines [13, 45], its anti-proliferative effect occurs mainly through cell cycle arrest in the majority of NET cell lines $[28,30,46]$. This mechanism is likely predominant in primary cultures of pNETs and may contribute to disease stabilization observed in patients [14].

SSAs have a favorable safety profile in patients with NETs [6, 47]. Moreover, previous reports have shown that octreotide decreases PI3K/Akt pathway activity in pituitary and pancreatic adenocarcinoma cell lines $[17,18]$. Since we have previously shown efficacy of SSAs in pNETs primary cultures [20], it was tempting to perform co-treatments of everolimus with SSAs to improve everolimus efficacy. Unfortunately, we cannot evidence any increase in either cell viability inhibition nor in the inhibition of $\mathrm{CgA}$ secretion in combined treatments (except in one pNET for each parameter analyzed). Similar observations have been made on primary cultures of human bronchial carcinoids treated with everolimus and pasireotide, although bronchial carcinoid cells are less responsive than pNETs cells to these agents as single treatments [48]. Lack of increase in the anti-proliferative effect of everolimus combined with octreotide has already been observed in the insulinoma rat cell line INS1, which is well sensitive to octreotide. In this cell line, both agents inhibit PI3K/Akt/mTOR pathway downstream of Akt through repression of TSC2, mTOR and p70S6K phosphorylation. Combined treatments did not enhance this effect, whereas Akt phosphorylation is not affected [31]. On the contrary, combined treatments of rapamycin and octreotide proved to be efficient in the pituitary cell line AtT20 and in human nonfunctioning pituitary adenoma cells in primary culture. In the AtT20 cells, octreotide increases IRS-1 phosphorylation that was suppressed by rapamycin, subsequently decreasing rapamycin-dependent Akt activation triggering cell cycle arrest through an increase in p27/kip1 level [30]. In human $\mathrm{pNET}$ cells octreotide and pasireotide do not repress the $\mathrm{PI} 3 \mathrm{~K} / \mathrm{Akt} / \mathrm{mTOR}$ pathway neither affect ERK1/2 pathway, although they decrease cell viability. Therefore, these pathways do not consistently mediate SSAs efficacy. In combined treatments with everolimus, SSAs are not able to repress everolimus-dependent Akt activation. Moreover, SSAs-dependent caspases activation is reverted, suggesting that persistent high level of P-Akt in combined treatments may counteract the cell death machinery elicited by SSAs by phosphorylation and inactivation of pro-apoptotic components [43]. Meric-Bernstam et al. recently showed that high level of P-Akt (detected in everolimus pre- and on-treatment tumor biopsies) correlated with longer PFS of patients carrying NET. They concluded that increase in P-Akt under everolimus treatment is not a marker of everolimus resistance but rather a marker of everolimus sensitivity [22]. In this clinical trial, all patients received octreotide LAR co-treatment [49], suggesting that, octreotide cannot repress everolimus-dependent Akt activation in the tumors of patients in vivo. These data are consistent with our results on primary cultures of pNETs.

Whereas decrease in objective response rate in combined treatments of everolimus and octreotide in clinical trial [19] may result from loss in caspasedependent apoptosis observed in pNETs cells in primary culture, PFS is increased. This could be explained by 
Table 3: Clinical and pathological information of pNET patients

\begin{tabular}{|c|c|c|c|c|c|c|c|c|c|c|c|c|}
\hline $\begin{array}{l}\text { Tumor } \\
\text { (number) }\end{array}$ & $\begin{array}{c}\text { Age } \\
\text { (year) }\end{array}$ & Sex & $\begin{array}{l}\text { Tumor } \\
\text { size } \\
(\mathrm{mm})\end{array}$ & $\begin{array}{c}\text { Liver } \\
\text { metastasis }\end{array}$ & $\begin{array}{l}\text { hormonal } \\
\text { secretion }\end{array}$ & $\mathbf{N}$ & $\begin{array}{l}\text { Ki67 } \\
(\%)\end{array}$ & mitosis & Grade & $\begin{array}{c}\text { cured after } \\
\text { surgery }\end{array}$ & $\begin{array}{c}\text { treatment } \\
\text { after surgery }\end{array}$ & $\begin{array}{c}\text { post- } \\
\text { surgical } \\
\text { follow-up }\end{array}$ \\
\hline 1 & 67 & $\mathrm{~F}$ & 44 & No & $\begin{array}{c}\text { non } \\
\text { functioning }\end{array}$ & $0 / 3 \mathrm{~N}$ & 1.5 & $3 / 10$ & G2 & No & $\begin{array}{l}\text { SSA started } \\
\text { recently for } \\
\text { appearance of } \\
\text { liver metastasis } \\
3 \text { years after } \\
\text { surgery }\end{array}$ & 3 years \\
\hline 2 & 53 & M & 15 & No & $\begin{array}{c}\text { non } \\
\text { functioning }\end{array}$ & NA & $<2$ & $<2 / 10$ & G1 & Yes & No & $\begin{array}{l}1 \text { year - } \\
\text { lost }\end{array}$ \\
\hline 3 & 44 & M & 40 & Yes & $\begin{array}{c}\text { non } \\
\text { functioning }\end{array}$ & $5 / 8 \mathrm{~N}$ & 5 & $4 / 10$ & G2 & No & $\begin{array}{l}\text { No (stable liver } \\
\text { metastasis) }\end{array}$ & 3 years \\
\hline 4 & 66 & $\mathrm{~F}$ & 55 & No & $\begin{array}{c}\text { non } \\
\text { functioning }\end{array}$ & $1 / 7 \mathrm{~N}$ & $<2$ & $1 / 10$ & G1 & Yes & No & 3 years \\
\hline $5(a)$ & 30 & $\mathrm{~F}$ & 40 & Yes & $\begin{array}{c}\text { non } \\
\text { functioning }\end{array}$ & $\mathrm{Nx}$ & 10 & $1 / 10$ & G2 & No & $\begin{array}{l}\text { progression } \\
\text { of liver } \\
\text { metastasis, } \\
\text { SSA started } \\
\text { recently } \\
\text { (somatuline) }\end{array}$ & 2 years \\
\hline 6 & 67 & M & 25 & No & $\begin{array}{c}\text { non } \\
\text { functioning }\end{array}$ & $0 / 1 \mathrm{~N}$ & 90 & $10 / 10$ & G3 & NA & NA & lost \\
\hline 7 & 75 & $\mathrm{~F}$ & 15 & No & $\begin{array}{c}\text { non } \\
\text { functioning }\end{array}$ & NA & $<1$ & $0 / 10$ & G1 & Yes & No & 6 month \\
\hline 8 & 59 & $\mathrm{~F}$ & 35 & No & $\begin{array}{c}\text { non } \\
\text { functioning }\end{array}$ & $3 / 16 \mathrm{~N}$ & 3 & NA & G2 & Yes & No & 4 years \\
\hline 9 & 76 & M & 48 & No & $\begin{array}{c}\text { non } \\
\text { functioning }\end{array}$ & $0 / 6 \mathrm{~N}$ & 5 & $2 / 10$ & G2 & Yes & No & 4 years \\
\hline 10 & 45 & M & 27 & No & $\begin{array}{c}\text { non } \\
\text { functioning }\end{array}$ & $0 / 6 \mathrm{~N}$ & 10 & $1 / 10$ & G2 & Yes & No & 1 year \\
\hline 11 & 49 & F & 45 & No & $\begin{array}{c}\text { non } \\
\text { functioning }\end{array}$ & $1 / 1 \mathrm{~N}$ & 13 & $15 / 10$ & G2 & Yes & No & 3 years \\
\hline 12 & 68 & M & 64 & No & $\begin{array}{c}\text { non } \\
\text { functioning }\end{array}$ & $0 / 15 \mathrm{~N}$ & 5 & $<1 / 10$ & G2 & $\begin{array}{l}\text { death after } \\
\text { surgery }\end{array}$ & NA & \\
\hline 13 & 65 & M & 12 & No & $\begin{array}{c}\text { non } \\
\text { functioning }\end{array}$ & NA & 4 & NA & G2 & Yes & No & 4 years \\
\hline 14 & 53 & $\mathrm{~F}$ & 15 & No & $\begin{array}{c}\text { non } \\
\text { functioning }\end{array}$ & NA & 5 & NA & G2 & Yes & No & 4 years \\
\hline 15 & 65 & M & 50 & No & $\begin{array}{c}\text { non } \\
\text { functioning }\end{array}$ & $5 / 27 \mathrm{~N}$ & 45 & $1 / 10$ & G3 & Yes & No & 3 years \\
\hline $16(b)$ & 36 & $\mathrm{~F}$ & $43(d)$ & No & $\begin{array}{c}\text { non } \\
\text { functioning }\end{array}$ & $0 / 12 \mathrm{~N}$ & 5 & $1 / 10$ & G2 & Yes & No & lost \\
\hline 17 & 66 & F & 50 & No & $\begin{array}{c}\text { non } \\
\text { functioning }\end{array}$ & $0 / 2 \mathrm{~N}$ & 6 & $<1 / 10$ & G2 & $\begin{array}{c}\text { No } \\
\text { ( appearance } \\
\text { of a liver } \\
\text { metastasis) }\end{array}$ & $\begin{array}{l}\text { chemotherapy } \\
\text { (Adriamycin } \\
\text { and } \\
\text { streptozotocin) }\end{array}$ & 4 years \\
\hline
\end{tabular}

(Continued) 


\begin{tabular}{|c|c|c|c|c|c|c|c|c|c|c|c|c|}
\hline $\begin{array}{l}\text { Tumor } \\
\text { (number) }\end{array}$ & $\begin{array}{c}\text { Age } \\
\text { (year) }\end{array}$ & Sex & $\begin{array}{c}\text { Tumor } \\
\text { size } \\
(\mathrm{mm})\end{array}$ & $\begin{array}{c}\text { Liver } \\
\text { metastasis }\end{array}$ & $\begin{array}{l}\text { hormonal } \\
\text { secretion }\end{array}$ & $\mathbf{N}$ & $\begin{array}{r}\text { Ki67 } \\
(\%)\end{array}$ & mitosis & Grade & $\begin{array}{c}\text { cured after } \\
\text { surgery }\end{array}$ & $\begin{array}{c}\text { treatment } \\
\text { after surgery }\end{array}$ & $\begin{array}{c}\text { post- } \\
\text { surgical } \\
\text { follow-up }\end{array}$ \\
\hline 18 & 48 & M & 80 & Yes & Insulinoma & $11 / 34 \mathrm{~N}$ & 10 & NA & G2 & No & $\begin{array}{l}\text { SSA then } \\
\text { Peptide } \\
\text { receptor } \\
\text { radionuclide } \\
\text { therapy (7 } \\
\text { cures) }\end{array}$ & 3 years \\
\hline 19(c) & 64 & M & $26(d)$ & No & gastrinoma & $0 / 30 \mathrm{~N}$ & $<2 \%$ & $<1 / 50$ & G1 & No & PPI & 5 years \\
\hline 20(a) & 44 & $\mathrm{~F}$ & 30 & Yes & $\begin{array}{c}\text { non } \\
\text { functioning }\end{array}$ & $6 / 19 \mathrm{~N}$ & 2 & NA & G1 & No & $\begin{array}{l}\text { percutaneous } \\
\text { thermoablation }\end{array}$ & 2 years \\
\hline 21 & 69 & $\mathrm{M}$ & 55 & No & $\begin{array}{c}\text { non } \\
\text { functioning }\end{array}$ & $1 / 2 \mathrm{~N}$ & $<1$ & $<1 / 10$ & G1 & Yes & No & 4 years \\
\hline 22 & 58 & $\mathrm{~F}$ & 70 & Yes & gastrinoma & $2 / 5 \mathrm{~N}$ & $<2$ & NA & G1 & NA & NA & lost \\
\hline 23 & 74 & $\mathrm{~F}$ & 40 & No & $\begin{array}{c}\text { non } \\
\text { functioning }\end{array}$ & $5 \mathrm{~N} / 11 \mathrm{~N}$ & 22 & NA & G3 & Yes & no & 1 year \\
\hline 24 & 30 & M & 75 & No & $\begin{array}{c}\text { non } \\
\text { functioning }\end{array}$ & $3 / 10 \mathrm{~N}$ & 40 & $24 / 10$ & G3 & $\begin{array}{l}\text { No (bone } \\
\text { metastasis) }\end{array}$ & $\begin{array}{l}\text { FOLFOX and } \\
\text { radiotherapy } \\
\text { on bone } \\
\text { mestastasis }\end{array}$ & $\begin{array}{c}1 \text { year- } \\
\text { death }\end{array}$ \\
\hline 25 & 41 & $\mathrm{~F}$ & 35 & No & $\begin{array}{c}\text { non } \\
\text { functioning }\end{array}$ & $0 / 3 \mathrm{~N}$ & 5 & $6 / 10$ & $\mathrm{G} 2$ & Yes & No & 1 year \\
\hline
\end{tabular}

Tumor size is expressed as maximal diameter (mm). For multiple localization, tumor size is the sum of each localization. (a) Tumor associated to MEN1 syndrome. (b) Tumor associated to VHL. (c) Patient treated with proton pump inhibitor (PPI) before surgery. (d) Multiple localization. NA (not available). N (lymph node). N: X/YN X positive nodes/Y analyzed nodes. Nx : no nodes were found in the resected specimen. Grade is determined according to WHO classification.

indirect mechanisms involving everolimus and SSAsinduced inhibition of tumor angiogenesis that might contained tumor growth [50]. As a matter of fact, GEPNETs are highly vascularized tumors expressing several growth factors and their corresponding receptors [51]. Among them, GEP-NETs synthesize and secrete high level of vascular endothelial growth factor (VEGF), a potent pro-angiogenic factor [52]. High expression of VEGF correlated with increased angiogenesis and decreased PFS [53]. Both SSAs [54, 55] and rapalogs [56] impaired VEGF production and secretion in tumors cells and particularly in NET cells [57, 58]. Moreover, they have been shown to control key steps of the angiogenic process: endothelial cell proliferation, endothelial tubule formation $[50,56,59-61]$ which could be involved in the PFS increase observed in SSA and everolimus combined treatments in clinical trials. In a phase III trial, sunitinib a multi-tyrosine kinase receptors inhibitor targeting the VEGF receptor improved PFS as compared to placebo in patients with advanced pNETs [62] and obtained approval from the FDA.

In conclusion, this study represents the first investigation of combined treatments of everolimus with octreotide or pasireotide in primary cultures of human
pNET cells. It shows that everolimus and SSAs repress cell viability and $\mathrm{CgA}$ secretion in single treatment, however their efficacy is not improved in combined treatments. These results are consistent with clinical reports showing that combined treatment do not induce a marked benefit for patients compared to everolimus single treatment. Akt activation by everolimus, unchallenged by SSAs, and loss of caspase-dependent apoptosis induced by SSAs are molecular events that strongly support this limited benefit. During the processing of our manuscript, Falletta et al. established a link between everolimus-dependent cell viability of pNET primary cultures, active Akt/mTOR/4EBP basal levels in the initial tumor tissue and the clinical aggressiveness of the tumor (high Ki67 index) [63]. In our study, we cannot highlight any correlation between cell viability or $\mathrm{CgA}$ secretion responses to everolimus and/or SSAs treatments and the WHO grade or Ki67 index of the initial tumor. Nevertheless, we observed good responses to everolimus or SSAs in some primary cultures from grade 3 tumors and/or Ki67 $\geq 10 \%$. No correlation could be established between treatments responses and MEN1 mutations, PTEN or DAXX/ATRX expression levels. This suggested that these available biomarkers are not predictive for the therapeutic response 
of pNETs to everolimus or SSAs [64]. Finally, primary culture of pNETs is a suitable preclinical model to further define biological effects and underlying mechanisms for new or other inhibitors of signaling pathways (Ras/ raf/MEK, PI3K, IGF1R...) previously described as potentially promising for co-targeted therapy in NET cell lines [45, 46, 65-67].

\section{PATIENTS AND METHODS}

\section{Patients}

The present study was approved by the Ethics Committee of the Aix-Marseille University (AixMarseille, France) and informed consent was obtained from each patient. Twenty five patients with pNET tumor were included in the study (Table 3). All the patients were bearing tumor requiring surgical removal. Patients were naïve of antitumor treatment before surgery. The only criterion for tumors selection was their identification as primary pNET or pNET derived metastasis by pathological analysis. Twenty four tumors were primary pNETs and one was a hepatic metastasis of a pNET. In 22 cases, there was no clinical or biochemical evidence of hormonal hypersecretion, thus they were considered as nonfunctional pNETs. In 3 cases, the tumors were secreting and symptomatic: insulinoma (tumor 18), and gastrinoma (tumors 19,22), confirmed by pathology reports. Determination of Ki67 and proliferation index allowed grade classification (WHO 2010 classification) (Table 3).

\section{Reagents}

Everolimus, octreotide and pasireotide, were provided by Novartis (Novartis AG, Basel Switzerland). All other reagents were purchased from Sigma-Aldrich (St Quentin Fallavier, France). Stock solutions of 10 ${ }^{2} \mathrm{M}$ everolimus were prepared in DMSO and kept at $-80^{\circ} \mathrm{C}$. Serial dilutions to obtain final concentrations of $10 \mathrm{nM}$ to $0.1 \mathrm{nM}$ everolimus were done directly in the culture medium containing 5\% Fetal calf serum (FCS) (corresponding final DMSO dilutions were from $10^{6}$ to $10^{8}$ fold). Stock solutions of octreotide $\left(10^{-3} \mathrm{M}\right)$ and pasireotide $\left(10^{-2} \mathrm{M}\right)$ were prepared into phosphate saline buffer containing $0.1 \%$ bovine serum albumin and $0.01 \mathrm{~N}$ acetic acid and kept at $-80^{\circ} \mathrm{C}$. Serial dilutions to obtain $1 \mathrm{nM}$ octreotide or pasireotide were done in the culture medium containing 5\% FCS. In combined treatments experiments, octreotide and pasireotide were diluted in the culture medium containing 5\% FCS and DMSO ( $10^{7}$ fold dilution) when used as single treatment (diluted in vehicle). Culture medium containing 5\% FCS and DMSO ( $10^{7}$ fold dilution) was used in control conditions (vehicle) in all the experiments containing everolimus.
We have previously shown that $1 \mathrm{nM}$ octreotide or pasireotide were effective on pNET primary culture [20]. These concentrations are close to their blood plasma levels (range 2-6nM for octreotide and 4-15nM for pasireotide) in patients treated monthly with 30$120 \mathrm{mg}$ octreotide LAR or $20-60 \mathrm{mg}$ pasireotide LAR respectively $[25,26]$.

\section{Cell culture}

Primary cultures of human pNETs were performed as previously described [20]. Tumor fragments of the 25 human pNETs, obtained after surgery, were dissociated mechanically and enzymatically [68]. Tumor cells were seeded into 24- or 6-well plates (according to the experiments) coated with extracellular matrix (ECM) (from bovine endothelial corneal cells as previously described [68]). Cells were maintained in culture in D-Valine DMEM, supplemented with $10 \%$ fetal calf serum (FCS), penicillin $(100 \mathrm{U} / \mathrm{ml})$, streptomycin $(100 \mu \mathrm{g} / \mathrm{ml})$, and glutamine $(100 \mathrm{U} / \mathrm{ml})$, at $37^{\circ} \mathrm{C}$ in a water-saturated atmosphere containing 7\% CO2. Cell viability determination and chromogranin $\mathrm{A}(\mathrm{CgA})$ secretion were carried out on cell cultures from 22 and 20 tumors respectively. Other experiments were performed according to the quantity of available tumor cells after dissociation of each tumor (range: $1.510^{6}$ to $5010^{6}$ cells). The number of primary cultures used for each experiment is indicated in the figure legends. All the experiments were done in D-Valine DMEM containing $5 \%$ FCS.

\section{Genomic analysis of $M E N 1$}

Formalin-fixed, paraffin-embedded tissue sections (FFPE) of $5 \mu \mathrm{m}$ from $25 \mathrm{pNETs}$ were used for DNA extraction. One to three slides from each pNET were extracted with the QIAamp DNA FFPE Tissue Kit (Qiagen, Courtaboeuf, France) according to the size of tumor section. Briefly, xylene was applied on the slide and paraffin embedded tumor was scratched into a microfuge tube containing xylene. Extraction was then performed according to the manufacturers' protocol. Purity and concentration of DNA were assessed using a Nanodrop ND-1000.

The coding exons and exon-intron boundaries of the MEN1 gene (NM_003977.2) were PCR amplified and screened by direct sequencing using specific primers on an ABI 3500XLDx (Applied Biosystems). Genetic analysis was performed with variant reporter software and pathogenicity of allelic variations were evaluated in silico using a battery of different bioinformatics algorithms (Polyphen2, UMD-predictor and Alamut 2.2.0 software [69]. Only variants classified as probably pathogenic or pathogenic were considered (Table 1). 


\section{Immunohistochemistry of PTEN, ATRX and DAXX}

Immunohistochemical labeling was performed on $4 \mu \mathrm{m}$ unstained slide sections from Tissue microarray (TMA). Slides were deparaffinized and subjected to antigen retrieval. Immunolabelings for ATRX (rabbit Anti-ATRX antibody, dilution 1/400 (SigmaAldrich, Cat. \# HPA001906)) and DAXX (rabbit AntiDAXX antibody, dilution 1/100 (Sigma-Aldrich, Cat. \# HPA008736)) were performed on the automated Ventana. Immunolabeling for PTEN (mouse Anti-PTEN antibody, dilution 1/50 (Dako, Les Ulis, France, Cat. \# $6 \mathrm{H} 2.1)$ ) were performed on the automated Dako. The expression was scored using stromal cells as a positive internal control. For ATRX and DAXX, positive case was defined as nuclear staining within tumor cells and negative staining was defined as lacked nuclear immunolabeling. For PTEN, only cytoplasmic staining was studied: low cytoplasmic staining was defined as 1 and moderate to intense cytoplasmic immunolabeling as 2 and 3 respectively.

\section{Real-time quantitative PCR}

Total mRNAs were extracted from $3 \times 10^{5}$ cells using the RNeasy Microkit (Qiagen). SST2 receptor mRNAs were detected by real-time quantitative PCR using specific primers and probes as previously described [70]. To produce standard curve, cDNA construct was produced, verified by sequencing and linearized. The mRNA level of SST2 was normalized to the glucuronidase $\beta$ (GUS $\beta$ ) mRNA level, as previously described [70]. Results were expressed as copy of mRNA for the SST2 gene/copy of mRNA for GUS $\beta$.

\section{Cell viability}

Cells from each tumor were seeded into 24-well plates $\left(4 \times 10^{4}\right.$ cells/well). After $24 \mathrm{~h}$ in culture, cells were treated or not with the different pharmacological agents, as indicated in the figure legends, for $72 \mathrm{~h}$. The medium was recovered for $\mathrm{CgA}$ determination and cell viability was assayed by a luminescent assay (CellTiter Glo; Promega, Charbonnières les Bains, France) according to the manufacturer's protocol. Results were expressed as percentages of the value for control cells (in the absence of treatment).

\section{CgA secretion}

$\mathrm{CgA}$ secretion was determined on the medium recovered from cell viability experiments after $72 \mathrm{~h}$ of treatment (see above). The recovered culture media were centrifuged at $400 \mathrm{~g}$ and stored at $-20^{\circ} \mathrm{C}$. CgA was measured using an Elisa kit (Chromogranin A Elisa Kit, Dako) according to the manufacturer's protocol. $\mathrm{CgA}$ values were normalized to the corresponding cell viability values. Results were expressed as percentages of the value for the control conditions.

\section{Caspase activity determination}

Cells from each tumor were seeded into 24-well plates $\left(4 \times 10^{4}\right.$ cells/well). After $24 \mathrm{~h}$ in culture, cells were treated with the different pharmacological agents for $24 \mathrm{~h}$. The activity of the executioner caspases 3 and 7 was measured using Caspase Glo 3/7 Assay (Promega) according to the manufacturer's protocol. Results were expressed as a percentage of the value for the control conditions.

\section{Protein extraction and western blotting}

Cells from each tumor were seeded into 6-well plates $\left(0.5 \times 10^{6}\right.$ cells/well). After $24 \mathrm{~h}$ in culture, cells were treated or not with the different pharmacological agents, as indicated in the figure legends. Cells were then solubilized at $4^{\circ} \mathrm{C}$ for $15 \mathrm{~min}$ in a lysis buffer $[25 \mathrm{mM}$ Tris $(\mathrm{pH} 7.4)$, $150 \mathrm{mM} \mathrm{NaCl}, 1 \%$ Nonidet P-40, $0.25 \%$ deoxycholate, $1 \mathrm{mM}$ EGTA, 1mM 4-(2-aminoethyl)benzenesulfonyl fluoride (AEBSF), $1 \mathrm{mM} \mathrm{Na}_{3} \mathrm{VO}_{4}$, and $10 \mu \mathrm{g} / \mathrm{ml}$ leupeptin and aprotinin] as previously described [27]. Denatured proteins were separated on $10 \%$ SDS-PAGE and transferred to PVDF membrane (Perkin Elmer, France). Immunodetection of the $\beta$ actin and the phosphorylated levels of Akt, ERK1/2 and p70S6K was performed using the mouse monoclonal anti- $\beta$-actin (Sigma-Aldrich, Cat. \# A5441), the polyclonal phospho-AktSer473 (Cat. \# 9271), phospho-p44/42ERK1/2 (Cat. \# 9101), the monoclonal phospho-p70S6KThr389 (Cat. \# 9234) rabbit antibodies respectively (New England Biolab, Ozyme, France) and an anti-mouse IgG or anti-Rabbit IgG coupled to alkaline phosphatase as the secondary antibody. Blots were developed with the enhanced chemiluminescence CDPStar ${ }^{\mathrm{TM}}$ detection system (Life Technologies, France) and quantified using Syngene and Genetools sofwares (Gbox, Ozyme, France). The total Akt, ERK1/2 and p70S6K content was systematically monitored by reprobing the membrane using the polyclonal Akt (Cat. \# 9272), the monoclonal p70S6K (Cat. \# 2708) rabbit antibodies (New England Biolab, Ozyme, France) and the polyclonal ERK1 antiserum (Santa Cruz Biotechnology, Tebu, France, Cat. \# sc-94). The relative expression of phospho-Akt, phosphoERK2 and phospho-p70S6K was calculated as a ratio to each total protein respectively and expressed in percent of the control value.

\section{Statistical analysis}

Each assay was performed in triplicate except for immunoblotting determinations. Results are presented as the mean \pm SEM of at least three tumors. The statistical significance between groups was determined by the 
paired Wilcoxon nonparametric test or Student's t-test and unpaired Mann-Whitney test. To measure the strength of association between pairs of variables without specifying dependency, Spearman rank order correlations were run. To measure the link between two qualitative parameters, Chi square test was performed. Differences were considered statistically significant at $\mathrm{p} \leq 0.05$.

\section{ACKNOWLEDGMENTS}

We would like to express our gratitude to Jérôme Cros (INSERM U1149, Clichy, France) for helpful discussion on TMA experiments, Emilie AgavnianCouquiaud (Paoli Calmettes Cancer Institute, Marseille, France) and Christophe Lisbonis (UMR7286, Marseille, France) for technical assistance.

\section{DECLARATION OF INTEREST}

The study was partially supported by Novartis Pharma SAS.

\section{GRANT SUPPORT}

This work was supported by Centre National pour la Recherche Scientifique (UMR 7286), AixMarseille Université, Association pour le Developpement des Recherches Biologiques et Médicales au Centre Hospitalier Régional de Marseille (A.D.E.R.E.M.), Protisvalor Méditerranée (Aix-Marseille Université) and Novartis Pharma SAS. A. Mohamed was a recipient of a fellowship from the A.D.E.R.E.M. D. Romano was a recipient of a fellowship from Fondation ARC.

\section{REFERENCES}

1. Yao JC, Hassan M, Phan A, Dagohoy C, Leary C, Mares JE, Abdalla EK, Fleming JB, Vauthey JN, Rashid A, Evans DB. One hundred years after "carcinoid": epidemiology of and prognostic factors for neuroendocrine tumors in 35,825 cases in the United States. J Clin Oncol. 2008; 26: 3063-72.

2. Young K, Iyer R, Morganstein D, Chau I, Cunningham D, Starling N. Pancreatic neuroendocrine tumors: a review. Future Oncol. 2015; 11: 853-64.

3. Metz DC, Jensen RT. Gastrointestinal neuroendocrine tumors: pancreatic endocrine tumors. Gastroenterology. 2008; 135: 1469-92.

4. Mahjoub AR, O'Reilly EM. Emerging therapies for pancreas neuroendocrine cancers. Chinese Clin Oncol. 2013; 2: 23.

5. Oberg K, Kvols L, Caplin M, Delle Fave G, de Herder W, Rindi G, Ruszniewski P, Woltering EA, Wiedenmann B. Consensus report on the use of somatostatin analogs for the management of neuroendocrine tumors of the gastroenteropancreatic system. Ann Oncol. 2004; 15: 966-73.
6. Caplin ME, Pavel M, Ćwikła JB, Phan AT, Raderer M, Sedláčková E, Cadiot G, Wolin EM, Capdevila J, Wall L, Rindi G, Langley A, Martinez S, et al. Lanreotide in metastatic enteropancreatic neuroendocrine tumors. N Engl J Med. 2014; 371: 224-33.

7. Rinke A, Muller HH, Schade-Brittinger C, Klose KJ, Barth P, Wied M, Mayer C, Aminossadati B, Pape UF, Blaker M, Harder J, Arnold C, Gress T, et al. PlaceboControlled, Double-Blind, Prospective, Randomized Study on the Effect of Octreotide LAR in the Control of Tumor Growth in Patients With Metastatic Neuroendocrine Midgut Tumors: A Report From the PROMID Study Group. J Clin Oncol. 2009; 27: 4656-63.

8. Jiao Y, Shi C, Edil BH, de Wilde RF, Klimstra DS, Maitra A, Schulick RD, Tang LH, Wolfgang CL, Choti MA, Velculescu VE, Diaz LA, Vogelstein B, et al. DAXX/ATRX, MEN1, and mTOR pathway genes are frequently altered in pancreatic neuroendocrine tumors. Science. 2011; 331: 1199-203.

9. Missiaglia E, Dalai I, Barbi S, Beghelli S, Falconi M, della Peruta M, Piemonti L, Capurso G, Di Florio A, delle Fave G, Pederzoli P, Croce CM, Scarpa A. Pancreatic endocrine tumors: expression profiling evidences a role for AKTmTOR pathway. J Clin Oncol. 2010; 28: 245-55.

10. Ghayouri M, Boulware D, Nasir A, Strosberg J, Kvols L, Coppola D. Activation of the serine/theronine protein kinase Akt in enteropancreatic neuroendocrine tumors. Anticancer Res. 2010; 30: 5063-7.

11. Zhou CF, Ji J, Yuan F, Shi M, Zhang J, Liu BY, Zhu ZG. mTOR activation in well differentiated pancreatic neuroendocrine tumors: a retrospective study on 34 cases. Hepatogastroenterology. 2011; 58: 2140-3.

12. Han X, Ji Y, Zhao J, Xu X, Lou W. Expression of PTEN and $\mathrm{mTOR}$ in pancreatic neuroendocrine tumors. Tumour Biol. 2013; 34: 2871-9.

13. Zitzmann K, De Toni EN, Brand S, Göke B, Meinecke J, Spöttl G, Meyer HHD, Auernhammer CJ. The novel mTOR inhibitor RAD001 (everolimus) induces antiproliferative effects in human pancreatic neuroendocrine tumor cells. Neuroendocrinology. 2007; 85: 54-60.

14. Yao JC, Shah MH, Ito T, Bohas CL, Wolin EM, Van Cutsem E, Hobday TJ, Okusaka T, Capdevila J, de Vries EGE, Tomassetti P, Pavel ME, Hoosen S, et al. Everolimus for advanced pancreatic neuroendocrine tumors. N Engl J Med. 2011; 364: 514-23.

15. O'Reilly KE, Rojo F, She QB, Solit D, Mills GB, Smith D, Lane H, Hofmann F, Hicklin DJ, Ludwig DL, Baselga J, Rosen N. mTOR inhibition induces upstream receptor tyrosine kinase signaling and activates Akt. Cancer Res. 2006; 66: 1500-8.

16. Carracedo A, Ma L, Teruya-Feldstein J, Rojo F, Salmena L, Alimonti A, Egia A, Sasaki AT, Thomas G, Kozma SC, Papa A, Nardella C, Cantley LC, et al. Inhibition of mTORC1 leads to MAPK pathway activation through a PI3K-dependent feedback loop in human cancer. J Clin Invest. 2008; 118: 3065-74. 
17. Bousquet C, Guillermet-Guibert J, Saint-Laurent N, ArcherLahlou E, Lopez F, Fanjul M, Ferrand A, Fourmy D, Pichereaux C, Monsarrat B, Pradayrol L, Estève JP, Susini C. Direct binding of $\mathrm{p} 85$ to sst2 somatostatin receptor reveals a novel mechanism for inhibiting PI3K pathway. EMBO J. 2006; 25: 3943-54.

18. Theodoropoulou M, Zhang J, Laupheimer S, Paez-Pereda M, Erneux C, Florio T, Pagotto U, Stalla GK. Octreotide, a somatostatin analogue, mediates its antiproliferative action in pituitary tumor cells by altering phosphatidylinositol 3-kinase signaling and inducing Zac1 expression. Cancer Res. 2006; 66: 1576-82.

19. Yao JC, Lombard-Bohas C, Baudin E, Kvols LK, Rougier P, Ruszniewski P, Hoosen S, St Peter J, Haas T, Lebwohl D, Van Cutsem E, Kulke MH, Hobday TJ, et al. Daily oral everolimus activity in patients with metastatic pancreatic neuroendocrine tumors after failure of cytotoxic chemotherapy: a phase II trial. J Clin Oncol. 2010; 28: 69-76.

20. Mohamed A, Blanchard MP, Albertelli M, Barbieri F, Brue T, Niccoli P, Delpero JR, Monges G, Garcia S, Ferone D, Florio T, Enjalbert A, Moutardier V, et al. Pasireotide and octreotide antiproliferative effects and sst2 trafficking in human pNET cultures. Endocr Relat Cancer. 2014; 21:691-704.

21. Singhi AD, Liu TC, Roncaioli JL, Cao D, Zeh HJ, Zureikat AH, Tsung A, Marsh JW, Lee KK, Hogg ME, Bahary N, Brand RE, McGrath KM, et al. Alternative Lengthening of Telomeres and Loss of DAXX/ATRX Expression Predicts Metastatic Disease and Poor Survival in Patients with Pancreatic Neuroendocrine Tumors. Clin Cancer Res. 2017; 23: 600-9.

22. Meric-Bernstam F, Akcakanat A, Chen H, Do KA, Sangai T, Adkins F, Gonzalez-Angulo AM, Rashid A, Crosby K, Dong M, Phan AT, Wolff RA, Gupta S, et al. PIK3CA/ PTEN mutations and Akt activation as markers of sensitivity to allosteric mTOR inhibitors. Clin Cancer Res. 2012; 18: 1777-89.

23. Thiery-Vuillemin A, Mouillet G, Nguyen Tan Hon T, Montcuquet P, Maurina T, Almotlak H, Stein U, Montange D, Foubert A, Nerich V, Pivot X, Royer B. Impact of everolimus blood concentration on its anti-cancer activity in patients with metastatic renal cell carcinoma. Cancer Chemother Pharmacol. 2014; 73: 999-1007.

24. Thudium K, Gallo J, Bouillaud E, Sachs C, Eddy S, Cheung W. Bioavailability of everolimus administered as a single $5 \mathrm{mg}$ tablet versus five $1 \mathrm{mg}$ tablets: a randomized, openlabel, two-way crossover study of healthy volunteers. Clin Pharmacol. 2015; 7: 11-7.

25. Woltering EA, Salvo VA, O’Dorisio TM, Lyons J, Li G, Zhou Y, Seward JR, Go VLW, Vinik AI, Mamikunian P, Mamikunian G. Clinical Value of Monitoring Plasma Octreotide Levels During Chronic Octreotide Long-Acting Repeatable Therapy in Carcinoid Patients. Pancreas. 2008; 37: 94-100.
26. Wolin EM, Hu K, Hughes G, Bouillaud E, Giannone V, Resendiz KH. Safety, tolerability, pharmacokinetics, and pharmacodynamics of a long-acting release (LAR) formulation of pasireotide (SOM230) in patients with gastroenteropancreatic neuroendocrine tumors: results from a randomized, multicenter, open-label, phase I stud. Cancer Chemother Pharmacol. 2013; 72: 387-95.

27. Pertuit M, Romano D, Zeiller C, Barlier A, Enjalbert A, Gerard C. The gsp oncogene disrupts Ras/ERK-dependent prolactin gene regulation in gsp inducible somatotroph cell line. Endocrinology. 2011; 152: 1234-43.

28. Gorshtein A, Rubinfeld H, Kendler E, Theodoropoulou M, Cerovac V, Stalla GK, Cohen ZR, Hadani M, Shimon I. Mammalian target of rapamycin inhibitors rapamycin and RAD001 (everolimus) induce anti-proliferative effects in GH-secreting pituitary tumor cells in vitro. Endocr Relat Cancer. 2009; 16: 1017-27.

29. Zatelli MC, Minoia M, Filieri C, Tagliati F, Buratto M, Ambrosio MR, Lapparelli M, Scanarini M, Degli Uberti EC. Effect of everolimus on cell viability in nonfunctioning pituitary adenomas. J Clin Endocrinol Metab. 2010; 95: 968-76.

30. Cerovac V, Monteserin-Garcia J, Rubinfeld H, Buchfelder M, Losa M, Florio T, Paez-Pereda M, Stalla GK, Theodoropoulou M. The somatostatin analogue octreotide confers sensitivity to rapamycin treatment on pituitary tumor cells. Cancer Res. 2010; 70: 666-74.

31. Grozinsky-Glasberg S, Franchi G, Teng M, Leontiou CA, Ribeiro de Oliveira A, Dalino P, Salahuddin N, Korbonits M, Grossman AB. Octreotide and the mTOR inhibitor RAD001 (everolimus) block proliferation and interact with the Akt-mTOR-p70S6K pathway in a neuro-endocrine tumour cell Line. Neuroendocrinology. 2008; 87: 168-81.

32. Moreno A, Akcakanat A, Munsell MF, Soni A, Yao JC, MericBernstam F. Antitumor activity of rapamycin and octreotide as single agents or in combination in neuroendocrine tumors. Endocr Relat Cancer. 2008; 15: 257-66.

33. Ito $\mathrm{T}$, Lee $\mathrm{L}$, Jensen RT. Treatment of symptomatic neuroendocrine tumor syndromes: recent advances and controversies. Expert Opin Pharmacother. 2016; 17: 2191-205.

34. Kulke MH, Bergsland EK, Yao JC. Glycemic control in patients with insulinoma treated with everolimus. N Engl J Med. 2009; 360: 195-7.

35. Fiebrich HB, Siemerink EJM, Brouwers AH, Links TP, Remkes WS, Hospers GAP, de Vries EGE. Everolimus Induces Rapid Plasma Glucose Normalization in Insulinoma Patients by Effects on Tumor As Well As Normal Tissues. Oncologist. 2011; 16: 783-7.

36. Bernard V, Lombard-Bohas C, Taquet MC, Caroli-Bosc FX, Ruszniewski P, Niccoli P, Guimbaud R, Chougnet CN, Goichot B, Rohmer V, Borson-Chazot F, Baudin E, French Group of Endocrine Tumors. Efficacy of everolimus in patients with metastatic insulinoma and refractory hypoglycemia. Eur J Endocrinol. 2013; 168: 665-74. 
37. Asayama M, Yamada-Murano T, Hara H, Ooki A, Kurosumi M, Yamaguchi K. Everolimus dramatically improves glycemic control in unresectable metastatic insulinoma: a case report. Jpn J Clin Oncol. 2014; 44: 186-90.

38. Bainbridge HE, Larbi E, Middleton G. Symptomatic Control of Neuroendocrine Tumours with Everolimus. Horm Cancer. 2015; 6: 254-9.

39. Li J, Song J, Cassidy MG, Rychahou P, Starr ME, Liu J, Li X, Epperly G, Weiss HL, Townsend CM, Gao T, Evers BM. PI3K p110 $\alpha$ /Akt signaling negatively regulates secretion of the intestinal peptide neurotensin through interference of granule transport. Mol Endocrinol. 2012; 26: 1380-93.

40. Valentino JD, Li J, Zaytseva YY, Mustain WC, Elliott VA, Kim JT, Harris JW, Campbell K, Weiss H, Wang C, Song J, Anthony L, Townsend CM, et al. Cotargeting the PI3K and RAS pathways for the treatment of neuroendocrine tumors. Clin Cancer Res. 2014; 20: 1212-22.

41. Giovinazzo F, Schimmack S, Svejda B, Alaimo D, Pfragner R, Modlin I, Kidd M. Chromogranin A and its fragments as regulators of small intestinal neuroendocrine neoplasm proliferation. PLoS One. 2013; 8: e81111.

42. Ortolani S, Ciccarese C, Cingarlini S, Tortora G, Massari F. Suppression of mTOR pathway in solid tumors: lessons learned from clinical experience in renal cell carcinoma and neuroendocrine tumors and new perspectives. Future Oncol. 2015; 11: 1809-28.

43. Datta SR, Brunet A, Greenberg ME. Cellular survival: a play in three Akts. Genes Dev. 1999; 13: 2905-27.

44. Fenton TR, Gout IT. Functions and regulation of the $70 \mathrm{kDa}$ ribosomal S6 kinases. Int J Biochem Cell Biol. 2011; 43: 47-59.

45. Zitzmann K, Rüden J von, Brand S, Göke B, Lichtl J, Spöttl G, Auernhammer CJ. Compensatory activation of Akt in response to mTOR and Raf inhibitors - a rationale for dual-targeted therapy approaches in neuroendocrine tumor disease. Cancer Lett. 2010; 295: 100-9.

46. Iida S, Miki Y, Ono K, Akahira J, Nakamura Y, Suzuki T, Sasano H. Synergistic anti-tumor effects of RAD001 with MEK inhibitors in neuroendocrine tumors: a potential mechanism of therapeutic limitation of mTOR inhibitor. Mol Cell Endocrinol. 2012; 350: 99-106.

47. Kvols LK, Oberg KE, O’Dorisio TM, Mohideen P, de Herder WW, Arnold R, Hu K, Zhang Y, Hughes G, Anthony L, Wiedenmann B. Pasireotide (SOM230) shows efficacy and tolerability in the treatment of patients with advanced neuroendocrine tumors refractory or resistant to octreotide LAR: results from a phase II study. Endocr Relat Cancer. 2012; 19: 657-66.

48. Zatelli MC, Minoia M, Martini C, Tagliati F, Ambrosio MR, Schiavon M, Buratto M, Calabrese F, Gentilin E, Cavallesco G, Berdondini L, Rea F, degli Uberti EC. Everolimus as a new potential antiproliferative agent in aggressive human bronchial carcinoids. Endocr Relat Cancer. 2010; 17: 719-29.
49. Yao JC, Phan AT, Chang DZ, Wolff RA, Hess K, Gupta S, Jacobs C, Mares JE, Landgraf AN, Rashid A, MericBernstam F. Efficacy of RAD001 (everolimus) and octreotide LAR in advanced low- to intermediate-grade neuroendocrine tumors: results of a phase II study. J Clin Oncol. 2008; 26: 4311-8.

50. Scoazec JY. Angiogenesis in neuroendocrine tumors: therapeutic applications. Neuroendocrinology. 2013; 97: $45-56$.

51. Fjällskog ML, Lejonklou MH, Oberg KE, Eriksson BK, Janson ET. Expression of molecular targets for tyrosine kinase receptor antagonists in malignant endocrine pancreatic tumors. Clin Cancer Res. 2003; 9: 1469-73.

52. Terris B, Scoazec JY, Rubbia L, Bregeaud L, Pepper MS, Ruszniewski P, Belghiti J, Fléjou J, Degott C. Expression of vascular endothelial growth factor in digestive neuroendocrine tumours. Histopathology. 1998; 32: 133-8.

53. Zhang J, Jia Z, Li Q, Wang L, Rashid A, Zhu Z, Evans DB, Vauthey JN, Xie K, Yao JC. Elevated expression of vascular endothelial growth factor correlates with increased angiogenesis and decreased progression-free survival among patients with low-grade neuroendocrine tumors. Cancer. 2007; 109: 1478-86.

54. Cascinu S, Del Ferro E, Ligi M, Staccioli MP, Giordani P, Catalano V, Agostinelli R, Muretto P, Catalano G. Inhibition of vascular endothelial growth factor by octreotide in colorectal cancer patients. Cancer Invest. 2001; 19: 8-12.

55. Mentlein R, Eichler O, Forstreuter F, Held-Feindt J. Somatostatin inhibits the production of vascular endothelial growth factor in human glioma cells. Int J cancer. 2001; 92: 545-50.

56. Guba M, von Breitenbuch P, Steinbauer M, Koehl G, Flegel S, Hornung M, Bruns CJ, Zuelke C, Farkas S, Anthuber M, Jauch KW, Geissler EK. Rapamycin inhibits primary and metastatic tumor growth by antiangiogenesis: involvement of vascular endothelial growth factor. Nat Med. 2002; 8: 128-35.

57. Zatelli MC, Piccin D, Vignali C, Tagliati F, Ambrosio MR, Bondanelli M, Cimino V, Bianchi A, Schmid HA, Scanarini M, Pontecorvi A, De Marinis L, Maira G, et al. Pasireotide, a multiple somatostatin receptor subtypes ligand, reduces cell viability in non-functioning pituitary adenomas by inhibiting vascular endothelial growth factor secretion. Endocr Relat Cancer. 2007; 14: 91-102.

58. Villaume K, Blanc M, Gouysse G, Walter T, Couderc C, Nejjari M, Vercherat C, Cordier-Bussat M, Roche C, Scoazec JY. VEGF secretion by neuroendocrine tumor cells is inhibited by octreotide and by inhibitors of the PI3K/AKT/mTOR pathway. Neuroendocrinology. 2010; 91: 268-78.

59. Woltering EA. Development of targeted somatostatin-based antiangiogenic therapy: a review and future perspectives. Cancer Biother Radiopharm. 2003; 18: 601-9. 
60. Phung TL, Ziv K, Dabydeen D, Eyiah-Mensah G, Riveros M, Perruzzi C, Sun J, Monahan-Earley RA, Shiojima I, Nagy JA, Lin MI, Walsh K, Dvorak AM, et al. Pathological angiogenesis is induced by sustained Akt signaling and inhibited by rapamycin. Cancer Cell. 2006; 10: 159-70.

61. Walter T, Hommell-Fontaine J, Gouysse G, Pourreyron C, Nejjari M, Villaume K, Causeret S, Hervieu V, Poncet G, Roche C, Scoazec JY. Effects of somatostatin and octreotide on the interactions between neoplastic gastroenteropancreatic endocrine cells and endothelial cells: A comparison between in vitro and in vivo properties. Neuroendocrinology. 2011; 94: 200-8.

62. Raymond E, Dahan L, Raoul JL, Bang YJ, Borbath I, Lombard-Bohas C, Valle J, Metrakos P, Smith D, Vinik A, Chen JS, Hörsch D, Hammel P, et al. Sunitinib malate for the treatment of pancreatic neuroendocrine tumors. N Engl J Med. 2011; 364: 501-13.

63. Falletta S, Partelli S, Rubini C, Nann D, Doria A, Marinoni I, Polenta V, Di Pasquale C, Degli Uberti E, Perren A, Falconi M, Zatelli MC. mTOR inhibitors response and mTOR pathway in pancreatic neuroendocrine tumors. Endocr Relat Cancer. 2016; 23: 883-91.

64. Modlin IM, Bodei L, Kidd M. Neuroendocrine tumor biomarkers: From monoanalytes to transcripts and algorithms. Best Pract Res Clin Endocrinol Metab. 2016; 30: 59-77.

65. Höpfner M, Baradari V, Huether A, Schöfl C, Scherübl H. The insulin-like growth factor receptor 1 is a promising target for novel treatment approaches in neuroendocrine gastrointestinal tumours. Endocr Relat Cancer. 2006; 13: 135-49.

66. Karhoff D, Sauer S, Schrader J, Arnold R, Fendrich V, Bartsch DK, Hörsch D. Rap1/B-Raf signaling is activated in neuroendocrine tumors of the digestive tract and Raf kinase inhibition constitutes a putative therapeutic target. Neuroendocrinology. 2007; 85: 45-53.

67. Passacantilli I, Capurso G, Archibugi L, Calabretta S, Caldarola S, Loreni F, Delle Fave G, Sette C. Combined therapy with RAD001 e BEZ235 overcomes resistance of PET immortalized cell lines to mTOR inhibition. Oncotarget. 2014; 5: 5381-91. doi: 10.18632/oncotarget.2111.

68. Jaquet P, Gunz G, Grisoli F. Hormonal regulation of prolactin release by human prolactinoma cells cultured in serum-free conditions. Horm Res. 1985; 22: 153-63.

69. Cuny T, Pertuit M, Sahnoun-Fathallah M, Daly A, Occhi G, Odou MF, Tabarin A, Nunes ML, Delemer B, Rohmer V, Desailloud R, Kerlan V, Chabre O, et al. Genetic analysis in young patients with sporadic pituitary macroadenomas: besides AIP don't forget MEN1 genetic analysis. Eur J Endocrinol. 2013; 168: 533-41.

70. Saveanu A, Gunz G, Dufour H, Caron P, Fina F, Ouafik L, Culler MD, Moreau JP, Enjalbert A, Jaquet P. Bim-23244, a somatostatin receptor subtype 2- and 5-selective analog with enhanced efficacy in suppressing growth hormone (GH) from octreotide-resistant human GH-secreting adenomas. J Clin Endocrinol Metab. 2001; 86: 140-5. 